\title{
Article \\ Performance Test for Sulfate Resistance of Concrete by Tensile Strength Measurements: Determination of Test Criteria
}

\author{
Johannes Haufe $1,2, *\left(\mathbb{0}\right.$, Anya Vollpracht ${ }^{2}$ and Thomas Matschei ${ }^{2}$ \\ 1 ZERTplus Überwachungsgesellschaft mbH, Mühlenweg 11, 06749 Bitterfeld-Wolfen, Germany \\ 2 Institute of Building Materials Research, Faculty of Civil Engineering, RWTH Aachen University, \\ Schinkelstraße 3, 52062 Aachen, Germany; vollpracht@ibac.rwth-aachen.de (A.V.); \\ matschei@ibac.rwth-aachen.de (T.M.) \\ * Correspondence: j.haufe@zertplus.de
}

Citation: Haufe, J.; Vollpracht, A.; Matschei, T. Performance Test for Sulfate Resistance of Concrete by Tensile Strength Measurements: Determination of Test Criteria. Crystals 2021, 11, 1018. https:// doi.org/10.3390/cryst11091018

Academic Editors: Yang Yu, Weiqiang Wang and Beatrice Pomaro

Received: 30 July 2021

Accepted: 23 August 2021

Published: 25 August 2021

Publisher's Note: MDPI stays neutral with regard to jurisdictional claims in published maps and institutional affiliations.

Copyright: (c) 2021 by the authors. Licensee MDPI, Basel, Switzerland. This article is an open access article distributed under the terms and conditions of the Creative Commons Attribution (CC BY) license (https:// creativecommons.org/licenses/by/ $4.0 /)$.

\begin{abstract}
The European standard EN 206-1 contains descriptive requirements for concrete to withstand sulfate attack in the field. This approach limits the use of feasible concrete mixtures that don't comply with these requirements. A performance approach based on the residual tensile strength of concrete briquet specimen according to ASTM C307 after storage in sodium sulfate solution close to field conditions is suggested by the authors. The newly developed test method is verified on a variety of 23 binders. Threshold values for the determination of the sulfate resistance of concrete after nine months of storage in $6000 \mathrm{mg} \mathrm{SO}_{4}{ }^{2-} / \mathrm{L}$ sulfate solution at $5{ }^{\circ} \mathrm{C}$ are proposed. A first repeatability test as well as thermodynamic calculations prove the suitability of the method to test the performance of concrete during sulfate attack under practical conditions.
\end{abstract}

Keywords: sulfate attack; concrete; tensile strength; thermodynamic modeling

\section{Introduction}

Hydrated aluminates and unreacted $\mathrm{C}_{3} \mathrm{~A}$ in concrete can react with sulfate containing aqueous solutions to form ettringite $\left(3 \mathrm{CaO} \cdot \mathrm{Al}_{2} \mathrm{O}_{3} \cdot 3 \mathrm{CaSO}_{4} \cdot 32 \mathrm{H}_{2} \mathrm{O}\right)$. This reaction is the main reaction during external sulfate attack (ESA) and is accompanied by a large increase in volume in relation to the solid reactants. Furthermore, the formation of gypsum can be observed. In the concrete matrix this leads to excessive expansion and the formation of cracks, surface spalling, delamination and the loss of mechanical strength [1,2].

Worldwide a multitude of test methods exist to evaluate the sulfate resistance of cement and concrete. In most cases laboratory experiments are preferred to field studies. In the laboratory constant test conditions can be ensured and the overall cost is comparably low. In these tests mortar or concrete samples are stored in artificial sulfate solutions. Different cations such as $\mathrm{Mg}^{2+}[3-8], \mathrm{Na}^{+}$[9-18], $\mathrm{Ca}^{2+}$ or combinations [19] are used, covering a large variety of sulfate concentrations. However, often unrealistically high sulfate concentrations $\geq 30,000 \mathrm{mg} \mathrm{SO}_{4}{ }^{2-} / \mathrm{L}$ are used to accelerate potentially deleterious reactions.

In Germany the standard test method for sulfate resistance testing is the so called SVA method (SVA: German expert committee responsible for assessing the performance and normative compliance of construction products), which is based on the Wittekindtmethod [20]. Both methods are based on the evaluation of the expansion of mortar flat prisms $\left(10 \times 40 \times 160 \mathrm{~mm}^{3}\right)$ stored in a highly concentrated sodium sulfate solution with $30,000 \mathrm{mg} \mathrm{SO}{ }_{4}{ }^{2-} / \mathrm{L}$. Originally designed to be conducted at ambient temperatures of $20^{\circ} \mathrm{C}$, the SVA method nowadays also includes testing at $5^{\circ} \mathrm{C}$ to take the low temperatures usually found in German soils and groundwater into account. Recently storage of additional samples is also required at $3000 \mathrm{mg} \mathrm{SO}{ }_{4}{ }^{2-} / \mathrm{L}$ to imitate a more realistic attack mechanism which is closer to the conditions present in the field [21]. The expansion of the sulfate exposed prisms is compared to reference samples stored in a saturated lime solution. A maximum permitted difference between the expansion in sulfate and reference solution 
was defined for storage in $30,000 \mathrm{mg} \mathrm{SO} 4^{2-/ L}$ at $20{ }^{\circ} \mathrm{C}: 0.5 \mathrm{~mm} / \mathrm{m}$ after 91 days and $0.8 \mathrm{~mm} / \mathrm{m}$ after 180 days. However, no criteria are defined for storage conditions at lower sulfate concentrations. Therefore, the expert committee decided that the test must be conducted over a period of two years. Mixtures containing sulfate resistant CEM I SR3 and blastfurnace slag cement (CEM III/B) are taken as a reference to ensure the sulfate resistance of the tested binder.

As previously pointed out by the authors, the resistance of concrete to sulfate attack is always dependent on both physical and chemical properties [22]. Consequently, an ideal test method should be able to account for both parameters. For example, the SVA method is designed as binder test only and does not consider the effect of lowering the permeability of concrete e.g., due to lowering the water/cement ratio to achieve a better sulfate resistance. We therefore propose that a sulfate resistance test should be performed using a realistic concrete mix design.

A test method based on the measurement of the relative tensile strength of concrete prisms $\left(40 \times 40 \times 160 \mathrm{~mm}^{3}\right)$, maximum grain size $\left.8 \mathrm{~mm}\right)$ has been developed by Mulenga [23]. The specimens were vacuum saturated for $24 \mathrm{~h}$ and subsequently stored in frequently renewed sodium sulfate solution with $33,900 \mathrm{mg} \mathrm{SO}_{4}{ }^{2-} / \mathrm{L}$ at $8{ }^{\circ} \mathrm{C}$ until testing after 84 and 120 days of storage.

Testing the tensile strength of concrete prisms requires high efforts concerning the sample preparation. Recently, a new test setup for tensile strength testing of sulfate stored concrete briquets according to ASTM C307-03 was therefore proposed by the authors [22]. The design of these specimens allows a fast testing since no carefully aligned stamps need to be glued to the side surfaces of the prism or cylinder as described by the MNS method [23]. The geometry of the specimen has been optimized to achieve relatively low scatter, allowing a better detection of damage [24]. In earlier extensive research we elaborated the optimum boundary conditions concerning storage conditions and test duration for the test procedure [25]. This study gives an overview of the proposed test setup including an assessment of the results.

\section{Experimental}

\subsection{Materials}

The sulfate resistance of concrete was assessed using a variety of 23 binders (cf. Table 1) in combination with a constant concrete mix design (see Section 2.2.3). The binders were selected to represent a large variety of cements according to EN 197: Portland cement, Portland composite cements and blastfurnace slag cements (CEM III) were considered. Amongst the tested cements were also several which are classified as "sulfate resistant" (SR). Additionally, three siliceous fly ashes were tested in combination with a Portland cement CEM I $42.5 \mathrm{~N}$.

Table 1. Overview on the selected binders.

\begin{tabular}{cc}
\hline & CEM I 32.5 R (supplier 1) \\
Portland cement & CEM I 42.5 N (supplier 2) \\
& CEM I 42.5 R (supplier 1) \\
Sulfate resistant Portland cement & CEM I 52.5 R (supplier 3) \\
\hline \multirow{2}{*}{ Portland composite cement without slag } & CEM I 42.5 N-SR3 (supplier 1) \\
& CEM II/B-V 32.5 R (supplier 2) \\
& CEM II/B-P 32.5 N (supplier 5) \\
& CEM II/B-M (S-P) 32.5 R (supplier 5) \\
& CEM II/ A-LL 42.5 N (supplier 1) \\
CEM II/ A-LL 42.5 N (supplier 3) \\
CEMtland composite cement with slag & CEM II/ A-S 42.5 N (supplier 7) \\
\hline \multirow{2}{*}{ CEM II/B-S 42.5 N (supplier 2) } \\
\hline
\end{tabular}


Table 1. Cont.

\begin{tabular}{cc}
\hline blastfurnace slag cement & CEM III/A 42.5 N (supplier 2) \\
CEM III/ A 42.5 N (supplier 1) \\
\hline sulfate resistant blastfurnace slag cement & CEM III/A 42.5 N SR (supplier 7) \\
& CEM III/ A 42.5 N LH/SR/NA (supplier 4) \\
CEM III/B 42.5 N LH/SR (supplier 7) \\
CEM III/B 42.5 N LH/SR/NA (supplier 1) \\
\hline siliceous fly ash & Fly ash 1 (supplier 8) \\
& Fly ash 2 (supplier 9) \\
& Fly ash 3 (supplier 10) \\
\hline
\end{tabular}

The chemical compositions of the cements and fly ashes are shown in Tables 2 and 3. Tables 4 and 5 contain their mineralogical compositions. The chemical composition of the materials was determined according to EN 196-2 by X-ray fluorescence, the chloride content by titration with silver nitrate solution and the $\mathrm{SO}_{3}$ content by gravimetric analysis. To determine the mineralogical composition a PANalytical X'Pert Pro X-ray diffractometer was used. The amorphous content was evaluated as described in [26] by using rutile as an internal standard at a replacement level of $20 \mathrm{wt} \%$.

Table 2. Chemical composition of the cements (in $\mathrm{wt} \%$ ).

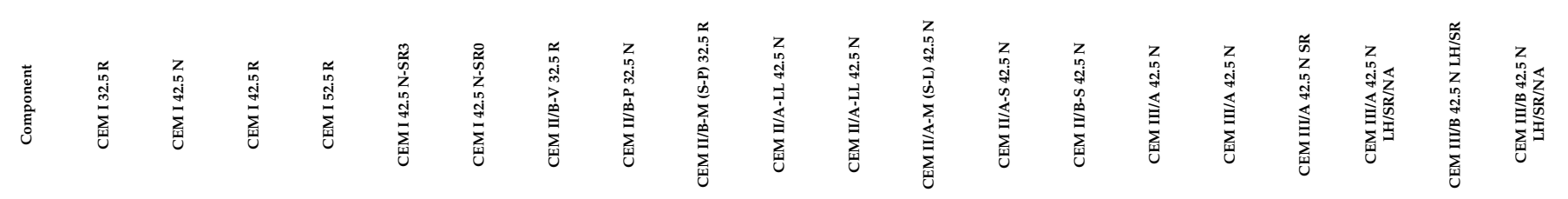

\begin{tabular}{|c|c|c|c|c|c|c|c|c|c|c|c|c|c|c|c|c|c|c|c|c|}
\hline № & 1 & 2 & 3 & 4 & 5 & 6 & 7 & 8 & 9 & 10 & 11 & 12 & 13 & 14 & 15 & 16 & 17 & 18 & 19 & 20 \\
\hline $\mathrm{CaO}$ & 64.2 & 64.7 & 63.9 & 64.9 & 62.8 & 62.7 & 44.5 & 47.4 & 49.5 & 62.9 & 62.4 & 59.1 & 59.9 & 55.5 & 49.8 & 56.1 & 52 & 49.5 & 48.4 & 52.4 \\
\hline $\mathrm{SiO}_{2}$ & 19.6 & 21.5 & 19.4 & 19.7 & 19.8 & 18.3 & 30.8 & 29.2 & 28.3 & 17.4 & 17.6 & 19.1 & 20.2 & 25.6 & 30.1 & 24.7 & 26.2 & 27.5 & 28.3 & 26.6 \\
\hline $\mathrm{Al}_{2} \mathrm{O}_{3}$ & 5.34 & 4.10 & 5.32 & 4.80 & 4.00 & 4.27 & 11.00 & 8.67 & 8.54 & 4.55 & 4.76 & 4.63 & 6.19 & 5.59 & 7.40 & 7.24 & 6.32 & 7.71 & 8.99 & 7.99 \\
\hline $\mathrm{Fe}_{2} \mathrm{O}_{3}$ & 2.55 & 2.71 & 2.47 & 2.59 & 6.55 & 7.49 & 4.49 & 3.18 & 2.74 & 1.83 & 3.13 & 2.30 & 2.82 & 1.83 & 1.17 & 1.74 & 2.92 & 1.29 & 1.29 & 1.53 \\
\hline $\mathrm{MgO}$ & 1.38 & 0.87 & 1.45 & 0.78 & 1.38 & 0.74 & 1.31 & 1.68 & 2.23 & 0.80 & 1.95 & 2.73 & 2.58 & 2.58 & 4.36 & 3.01 & 5.32 & 5.41 & 4.91 & 3.62 \\
\hline $\mathrm{K}_{2} \mathrm{O}$ & 0.71 & 0.62 & 0.70 & 0.31 & 1.01 & 0.60 & 1.38 & 2.42 & 1.80 & 0.60 & 0.91 & 0.67 & 1.09 & 0.63 & 0.58 & 0.54 & 0.50 & 0.75 & 0.50 & 0.54 \\
\hline $\mathrm{Na}_{2} \mathrm{O}$ & 0.18 & 0.34 & 0.16 & 0.20 & 0.14 & 0.11 & 0.48 & 1.04 & 0.82 & 0.19 & 0.06 & 0.26 & 0.25 & 0.39 & 0.37 & 0.25 & 0.27 & 0.36 & 0.31 & 0.27 \\
\hline $\mathrm{TiO}_{2}$ & 0.30 & 0.18 & 0.28 & 0.25 & 0.14 & 0.22 & 0.47 & 0.36 & 0.45 & 0.25 & 0.29 & 0.26 & 0.35 & 0.33 & 0.49 & 0.57 & 0.47 & 0.56 & 0.74 & 0.70 \\
\hline $\mathrm{Cl}^{-}$ & 0.019 & 0.056 & 0.020 & 0.022 & 0.054 & 0.016 & 0.031 & 0.021 & 0.020 & 0.020 & 0.019 & 0.023 & 0.021 & 0.028 & 0.061 & 0.031 & 0.017 & 0.023 & 0.018 & 0.020 \\
\hline $\mathrm{SO}_{3}$ & 2.88 & 2.76 & 3.06 & 2.54 & 2.56 & 3.16 & 1.94 & 2.68 & 2.61 & 3.16 & 2.96 & 2.79 & 2.55 & 2.81 & 3.13 & 2.78 & 2.84 & 2.75 & 2.89 & 2.65 \\
\hline LOI & 2.07 & 2.39 & 2.43 & 3.14 & 1.82 & 2.68 & 2.67 & 2.53 & 1.79 & 7.14 & 5.55 & 7.50 & 2.40 & 0.41 & -0.96 & 1.29 & 1.56 & 1.12 & -0.32 & 0.44 \\
\hline
\end{tabular}

Table 3. Chemical composition of the fly ashes (in $\mathrm{wt} \%$ ).

\begin{tabular}{cccc}
\hline Component & Fly Ash $\mathbf{1}$ & Fly Ash 2 & Fly Ash 3 \\
\hline $\mathbf{N o}$ & $\mathbf{2 1}$ & $\mathbf{2 2}$ & $\mathbf{2 3}$ \\
\hline $\mathrm{CaO}$ & 3.20 & 4.81 & 5.59 \\
$\mathrm{SiO}_{2}$ & 50.1 & 52.8 & 53.7 \\
$\mathrm{Al}_{2} \mathrm{O}_{3}$ & 25.8 & 24.9 & 21.7 \\
$\mathrm{Fe}_{2} \mathrm{O}_{3}$ & 7.29 & 7.25 & 8.53 \\
$\mathrm{MgO}$ & 1.64 & 1.67 & 2.36 \\
$\mathrm{~K}_{2} \mathrm{O}$ & 2.03 & 1.65 & 2.23 \\
$\mathrm{Na}_{2} \mathrm{O}$ & 0.91 & 0.56 & 1.35 \\
$\mathrm{TiO}_{2}$ & 0.93 & 1.32 & 0.92 \\
$\mathrm{Cl}^{-}$ & $<0.001$ & 0.014 & 0.104 \\
$\mathrm{SO}_{3}$ & 0.65 & 0.77 & 1.18 \\
$\mathrm{LOI}$ & 4.72 & 2.96 & 1.38 \\
\hline
\end{tabular}


Table 4. Mineralogical composition of the cements (in $\mathrm{wt} \%$ ).

\begin{tabular}{|c|c|c|c|c|c|c|c|c|c|c|c|c|c|c|c|c|c|c|c|c|}
\hline 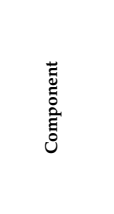 & 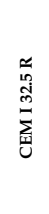 & 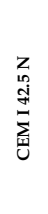 & 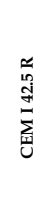 & 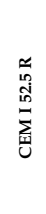 & 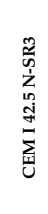 & 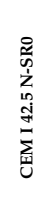 & 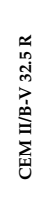 & 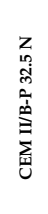 & 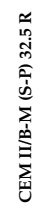 & 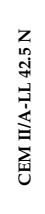 & 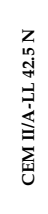 & 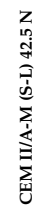 & 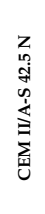 & 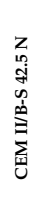 & 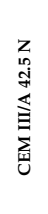 & 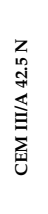 & 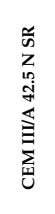 & 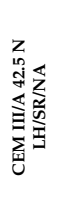 & 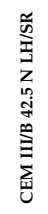 & 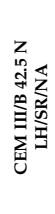 \\
\hline № & 1 & 2 & 3 & 4 & 5 & 6 & 7 & 8 & 9 & 10 & 11 & 12 & 13 & 14 & 15 & 16 & 17 & 18 & 19 & 20 \\
\hline Alite & 56.8 & 57.6 & 58.7 & 60.6 & 53.8 & 62.4 & 30.8 & 29.6 & 31.3 & 52.8 & 52.8 & 33.5 & 34.8 & 33.5 & 18.6 & 27.8 & 21.0 & 16.9 & 14.1 & 20.6 \\
\hline $\begin{array}{c}\text { Belite } \\
\mathrm{C}_{3} \mathrm{~A}\end{array}$ & $\begin{array}{l}12.5 \\
11.8\end{array}$ & $\begin{array}{l}13.0 \\
7.4\end{array}$ & $\begin{array}{c}9.4 \\
13.0\end{array}$ & $\begin{array}{l}14.2 \\
9.2\end{array}$ & $\begin{array}{l}9.6 \\
3.0\end{array}$ & $\begin{array}{l}2.3 \\
5.3\end{array}$ & $\begin{array}{l}7.0 \\
4.0\end{array}$ & $\begin{array}{l}7.1 \\
2.2\end{array}$ & $\begin{array}{l}8.5 \\
4.3\end{array}$ & $\begin{array}{l}7.4 \\
7.5\end{array}$ & $\begin{array}{l}5.8 \\
11.3\end{array}$ & $\begin{array}{l}8.2 \\
2.8\end{array}$ & $\begin{array}{l}5.1 \\
5.9\end{array}$ & $\begin{array}{l}6.1 \\
5.0\end{array}$ & $\begin{array}{l}4.1 \\
2.7\end{array}$ & $\begin{array}{l}5.1 \\
5.3\end{array}$ & $\begin{array}{l}7.0 \\
1.6\end{array}$ & $\begin{array}{l}2.9 \\
2.8\end{array}$ & $\begin{array}{l}2.2 \\
1.9\end{array}$ & $\begin{array}{l}5.3 \\
4.3\end{array}$ \\
\hline $\begin{array}{l}3^{\mathrm{A}} \\
\text { Ferrite }\end{array}$ & $\begin{array}{l}11.8 \\
6.4\end{array}$ & $\begin{array}{l}.4 .4 \\
6.3\end{array}$ & $\begin{array}{l}13.0 \\
5.5\end{array}$ & $\begin{array}{l}9.2 \\
5.9\end{array}$ & $\begin{array}{l}3.0 \\
19.9\end{array}$ & $\begin{array}{l}5.3 \\
19.4\end{array}$ & $\begin{array}{l}4.0 \\
3.9\end{array}$ & $\begin{array}{l}2.2 \\
3.3\end{array}$ & $\begin{array}{l}4.3 \\
3.3\end{array}$ & $\begin{array}{l}.7 .5 \\
9.3\end{array}$ & $\begin{array}{l}11.3 \\
2.9\end{array}$ & $\begin{array}{l}2.8 \\
3.9\end{array}$ & $\begin{array}{l}5.9 \\
5.7\end{array}$ & $\begin{array}{l}5.0 \\
2.9\end{array}$ & $\begin{array}{l}2.7 \\
2.1\end{array}$ & $\begin{array}{l}5.3 \\
2.5\end{array}$ & $\begin{array}{l}1.6 \\
5.5\end{array}$ & $\begin{array}{l}2.8 \\
1.6\end{array}$ & $\begin{array}{l}1.9 \\
1.8\end{array}$ & $\begin{array}{l}4.3 \\
1.9\end{array}$ \\
\hline Gypsum & 0.2 & 0.9 & & 3.4 & & 3.7 & 0.3 & 1.2 & 1.0 & 0.4 & 0.1 & 0.4 & & & & 0.3 & 0.2 & & & \\
\hline Hemihydrate & 2.8 & 2.0 & 3.2 & 2.4 & 0.7 & 1.0 & 0.6 & 1.3 & 1.1 & 4.6 & 2.0 & 3.0 & 2.6 & 1.1 & 0.4 & 1.7 & 0.6 & 0.7 & 0.3 & 1.7 \\
\hline $\begin{array}{l}\text { Anhydrite } \\
\text { Calcite }\end{array}$ & $\begin{array}{l}4.7 \\
22\end{array}$ & $\begin{array}{l}2.0 \\
57\end{array}$ & $\begin{array}{l}4.5 \\
16\end{array}$ & & $\begin{array}{l}5.4 \\
5.1\end{array}$ & 46 & 2.6 & 3.0 & 3.4 & ${ }^{2.7}$ & $\begin{array}{l}6.5 \\
10.8\end{array}$ & 0.1 & $\begin{array}{l}1.5 \\
27\end{array}$ & 3.8 & 4.5 & 2.2 & $\begin{array}{l}4.5 \\
.8\end{array}$ & 4.0 & 4.0 & 3.1 \\
\hline $\begin{array}{c}\text { Calcite } \\
\text { Periclase }\end{array}$ & $\begin{array}{l}2.2 \\
0.7\end{array}$ & 5.7 & $\begin{array}{l}1.6 \\
0.8\end{array}$ & 2.3 & $\begin{array}{l}5.1 \\
0.5\end{array}$ & $\begin{array}{l}4.6 \\
0.2\end{array}$ & $\begin{array}{l}0.3 \\
0.3\end{array}$ & 0.2 & & $\begin{array}{l}11.3 \\
1.0\end{array}$ & $\begin{array}{l}16.8 \\
0.2\end{array}$ & $\begin{array}{l}12.4 \\
0.3\end{array}$ & $\begin{array}{l}2.7 \\
0.4\end{array}$ & $\begin{array}{l}0.1 \\
0.2\end{array}$ & 0.2 & $\begin{array}{l}1.2 \\
0.3\end{array}$ & $\begin{array}{l}2.8 \\
15\end{array}$ & $\begin{array}{l}2.4 \\
02\end{array}$ & $\begin{array}{l}0.7 \\
0.2\end{array}$ & $\begin{array}{l}0.6 \\
0.3\end{array}$ \\
\hline $\begin{array}{l}\text { Periclase } \\
\text { Quartz }\end{array}$ & $\begin{array}{l}0.7 \\
0.5\end{array}$ & 1.1 & $\begin{array}{l}0.8 \\
0.6\end{array}$ & & $\begin{array}{l}0.5 \\
0.6\end{array}$ & $\begin{array}{l}0.2 \\
0.2\end{array}$ & $\begin{array}{l}0.3 \\
1.5\end{array}$ & $\begin{array}{l}0.2 \\
2.1\end{array}$ & $\begin{array}{l}0.3 \\
2.2\end{array}$ & $\begin{array}{l}1.0 \\
0.3\end{array}$ & $\begin{array}{l}0.2 \\
0.4\end{array}$ & $\begin{array}{l}0.3 \\
0.1\end{array}$ & $\begin{array}{l}0.4 \\
0.3\end{array}$ & $\begin{array}{l}0.2 \\
0.2\end{array}$ & 0.1 & $\begin{array}{l}0.3 \\
0.4\end{array}$ & $\begin{array}{l}1.5 \\
0.2\end{array}$ & $\begin{array}{l}0.2 \\
0.2\end{array}$ & $\begin{array}{l}0.2 \\
0.5\end{array}$ & 0.3 \\
\hline Arcanite & $\begin{array}{l}0.0 \\
1.0\end{array}$ & 1.7 & $\begin{array}{l}0.0 \\
2.3\end{array}$ & 0.3 & 0.7 & 0.8 & 0.5 & & & 1.7 & $\begin{array}{l}0.8 \\
0.8\end{array}$ & $\begin{array}{l}0.1 \\
0.3\end{array}$ & 0.5 & 0.1 & 0.1 & $\begin{array}{l}0.8 \\
0.8\end{array}$ & & 0.1 & 0.4 & 0.1 \\
\hline $\begin{array}{c}\mathrm{Ca} \\
\text { Lanobeinite }\end{array}$ & - & 0.9 & - & 0.6 & 0.6 & - & 0.3 & 1.7 & 1.1 & 0.7 & 0.4 & 0.6 & 1.7 & 0.8 & 0.5 & 0.4 & 0.2 & 0.4 & 1.2 & 0.7 \\
\hline $\begin{array}{l}\text { Lagveentue } \\
\text { Lime }\end{array}$ & & & & & & & & & & & & & & & & & - & 0.1 & 0.1 & \\
\hline $\begin{array}{l}\text { Portlantite } \\
\text { Mollite }\end{array}$ & 0.3 & 1.4 & 0.4 & 1.1 & - & - & $\begin{array}{l}0.2 \\
3.8\end{array}$ & 0.1 & 0.1 & 0.4 & 0.2 & 0.7 & 0.3 & 0.4 & 0.2 & 0.2 & - & 0.2 & 0.2 & 0.1 \\
\hline Hematitite & - & - & - & - & - & - & $\begin{array}{l}0.0 \\
0.6\end{array}$ & - & - & - & - & - & - & - & - & - & $=$ & $=$ & - & - \\
\hline $\begin{array}{l}\text { Magneti } \\
\text { Analcim }\end{array}$ & - & $\therefore$ & - & - & - & - & 0.3 & $\overline{48}$ & $-\overline{36}$ & - & - & - & - & - & - & - & - & - & - & - \\
\hline $\begin{array}{l}\text { Analait } \\
\text { Sanidi }\end{array}$ & - & $\therefore$ & - & 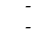 & 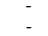 & $\therefore$ & - & $\begin{array}{l}4.8 \\
3.8\end{array}$ & $\begin{array}{l}3.6 \\
2.6\end{array}$ & - & - & - & 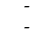 & $=$ & $=$ & $\therefore$ & : & $=$ & : & - \\
\hline Muscovite & - & - & - & - & - & - & - & 2.9 & 2.3 & - & - & - & & & - & - & - & - & & - \\
\hline $\begin{array}{l}\text { Phillipsite } \\
\text { Amorohous }\end{array}$ & - & : & - & 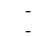 & & - & 43.0 & $\begin{array}{l}0.3 \\
36.5\end{array}$ & $\begin{array}{l}0.2 \\
34.6\end{array}$ & 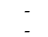 & : & 33.7. & $\overline{37.4}$ & $-\overline{45.6}$ & 66.7 & $\overline{51.5}$ & 54.7 & $\begin{array}{c}- \\
67.4\end{array}$ & $\overline{72.3}$ & 61.0 \\
\hline
\end{tabular}

Table 5. Mineralogical composition of the fly ashes (in $w \mathrm{t} \%$ ).

\begin{tabular}{cccc}
\hline Component & Fly Ash 1 & Fly Ash 2 & Fly Ash 3 \\
\hline No & $\mathbf{2 1}$ & $\mathbf{2 2}$ & $\mathbf{2 3}$ \\
\hline Mullite & 13.2 & 20.7 & 11.3 \\
Quartz & 4.8 & 12.5 & 12.7 \\
Gypsum & 0.1 & - & \\
Hemihydrate & 0.3 & 0.8 & 0.7 \\
Anhydrite & - & 0.5 & 0.8 \\
Calcite & 0.8 & - & - \\
Periclase & 0.2 & 0.4 & 0.7 \\
Lime & 0.1 & 0.3 & 1.0 \\
Hematite & 0.6 & 1.3 & 1.3 \\
Magnetite & 0.9 & 0.4 & 70.9 \\
Amorphous & 78.8 & 63.0 & \\
\hline
\end{tabular}

\subsection{Methods}

\subsubsection{Sulfate Resistance Testing Procedure}

The applied testing procedure (cf. [22]) is summarized below. Tensile strength measurements based on ASTM C307-03 [19] were used to assess the sulfate resistance of modified concrete mixes. The applied experimental boundary conditions were elaborated in an earlier study [22].

1. An adapted concrete mix design based on the planned concrete mixture should be used, including a reduction of the maximum aggregate size of $8 \mathrm{~mm}$. To shorten the duration of the test it is recommended to increase the water to binder ratio by $10 \%$. This causes a slightly increased permeability in order to accelerate the ingress of sulfate ions, but still provides a realistic concrete mix design, which is in alignment of the general concept to move towards a performance test.

2. Briquet molds according to ASTM C307-03 were used to produce the specimens for tensile strength testing in one single batch. After demolding the samples were stored in saturated $\mathrm{Ca}(\mathrm{OH})_{2}$ solution at $20^{\circ} \mathrm{C}$ until an age of 28 days.

3. The tensile strength of the concrete at an age of 28 days was determined and serves as the reference strength. 
4. The specimens dedicated for sulfate storage were stored in sodium sulfate solution with $6000 \mathrm{mg} \mathrm{SO}{ }_{4}{ }^{2-} / \mathrm{L}$ at $5{ }^{\circ} \mathrm{C}$ until tensile strength testing. The storage solution was renewed every 7 days until 28 days of storage and every 14 days afterwards to compensate for the consumption of sulfates.

5. The tensile strength of the concrete was tested after 119 days (4 months), 182 days (6 months) and 273 days ( 9 months) of storage in the solution.

The relative tensile strengths $\mathrm{f}_{\mathrm{t}} / \mathrm{f}_{\mathrm{tm}, 119 \mathrm{~d}}, \mathrm{f}_{\mathrm{t}} / \mathrm{f}_{\mathrm{tm}, 182 \mathrm{~d}}$ and $\mathrm{f}_{\mathrm{t}} / \mathrm{f}_{\mathrm{tm}, 273 \mathrm{~d}}$ were calculated using the reference strength determined after curing for 28 days and a maturity function to account for the ongoing hydration during the sulfate storage. This approach, originally designed to calculate the development of the compressive strength of concrete, was proven to give good results previously and is based on a study by Vollpracht et al. [27] and the fib Model code [28]. The tensile strength $\mathrm{f}_{\mathrm{tm}}$ at time $\mathrm{t}$ is calculated from the strength at 28 days using the following equation:

$$
f_{t m}(t)=\beta_{t c}(t) \cdot f_{t m, 28 d} \text { with } \beta_{t c}(t)=e^{s \cdot\left(1-\sqrt{\frac{28 d}{t}}\right)}
$$

where

- $f_{t m}(t)$ is the mean tensile strength in MPa at an age $t$ in days,

- $\mathrm{f}_{\mathrm{tm}, 28 \mathrm{~d}}$ is the average tensile strength in MPa at an age of 28 days,

- $\quad \beta_{\mathrm{tc}}(\mathrm{t})$ is a function to describe the strength development with time,

- $t$ is the concrete age in days,

- $\quad \mathrm{s}$ is a coefficient, which depends on the strength class of the cement, the water/binder ratio and the content of reactive supplementary cementitious material (SCM).

The s-value is calculated as follows:

$$
\mathrm{s}=\mathrm{c}_{1} \cdot \frac{\mathrm{w}}{\mathrm{b}}+\mathrm{c}_{2} \cdot \frac{\mathrm{scm}}{\mathrm{b}}
$$

where

- $\mathrm{w} / \mathrm{b}$ is the water to binder ratio,

- $\mathrm{scm} / \mathrm{b}$ is the mass proportion of the SCM in the binder,

- $\quad c_{1}, c_{2}$ are coefficients depending on the strength class of the cement.

For cements with the strength class $32.5 \mathrm{~N}, 32.5 \mathrm{R}$ and $42.5 \mathrm{~N}$ coefficients $\mathrm{c}_{1}=0.528$ and $c_{2}=0.527$ have been determined, for cements $42.5 \mathrm{R}, 52.5 \mathrm{~N}$ and $52.5 \mathrm{R}$ the coefficients were calculated to $c_{1}=0.481$ and $c_{2}=0.441$ [27]. To account for reactive SCM contained in CEM II and CEM III, the glass content measured by XRD was taken as an approximation in Equation (2).

To account for the influence of different storage temperatures of the concrete, the real concrete age $t$ (cf. Equation (3)) is replaced by a temperature-adjusted concrete age $t_{T}$ following the fib model code's maturity function as follows:

$$
\mathrm{t}_{\mathrm{T}}=\sum_{\mathrm{i}=1}^{\mathrm{n}} \Delta \mathrm{t}_{\mathrm{i}} \mathrm{e}^{\left[13.65-\frac{4000}{273+\mathrm{T}_{\alpha}\left(\Delta \mathrm{t}_{\mathrm{i}}\right)}\right]}
$$

where

- $t_{\mathrm{T}}$ is the temperature-adjusted concrete age in days,

- $\Delta \mathrm{t}_{\mathrm{i}}$ is the number of days where a temperature $\mathrm{T} \alpha$ prevails in days,

- $\mathrm{T}_{\alpha}\left(\Delta \mathrm{t}_{\mathrm{i}}\right)$ is the temperature of concrete during time interval $\Delta \mathrm{t}_{\mathrm{i}}$ in ${ }^{\circ} \mathrm{C}$.

\subsubsection{Expansion Testing on Mortar Flat Bars (SVA Test Method)}

For each binder or binder combination $450 \mathrm{~g}$ binder, $1350 \mathrm{~g}$ CEN reference sand and $225 \mathrm{~g}$ water were used. For binders containing fly ash $337.5 \mathrm{~g}$ (2) CEM I $42.5 \mathrm{~N}$ were mixed with $112.5 \mathrm{~g}$ fly ash. Mixing was performed according to EN 196-1. For each mixture so called flat prisms $\left(10 \times 40 \times 400 \mathrm{~mm}^{3}\right)$ were produced according to DIN EN 196-1. The flat 
prisms remained in the molds for two days at $20{ }^{\circ} \mathrm{C}$ and $>95 \% \mathrm{r}$. h. Afterwards the molds were removed and the specimens were stored in a saturated $\mathrm{Ca}(\mathrm{OH})_{2}$-solution at $20{ }^{\circ} \mathrm{C}$ up to an age of 14 days.

After the pre-storage, the specimens were stored in saturated $\mathrm{Ca}(\mathrm{OH})_{2}$-solution and in sodium sulfate solution with a sulfate content of 30,000 as well as $3000 \mathrm{mg} \mathrm{SO}{ }_{4}{ }^{2-} / \mathrm{L}$ at 5 and $20{ }^{\circ} \mathrm{C}$. The sulfate solution was renewed every two weeks for the first three months and every 28 days afterwards to ensure a constant sulfate concentration over time.

The ongoing deterioration of the mortar samples was monitored by length measurement and determination of the dynamic modulus of elasticity. Length changes of the prisms were measured using a digital indicator Mahr Millitast 1070. Measurements were conducted after 0,14, 56, 91, 180, 270 and 365 days of storage. The dynamic modulus of elasticity was assessed by measuring the resonance frequency at the same dates.

\subsubsection{Concrete Production and Curing for Tensile Strength Tests}

Concrete with $360 \mathrm{~kg}$ cement $/ \mathrm{m}^{3}$ was used for the evaluation of tensile strength evolution. The equivalent water to cement ratio was 0.50 . Rhine gravel and Rhine sand with a maximum grain size of $8 \mathrm{~mm}$ were used as aggregate for concrete production. Quartz powder was used as filler; a C 8 grading curve according to DIN 1045-2 was implemented. The summary of the applied concrete mix design is shown in Table 6.

Table 6. Composition of the concrete mixtures (assumed air content: 2 vol\%).

\begin{tabular}{|c|c|c|}
\hline Component & Concrete with Cement Only & Concrete with CEM I + Fly Ash \\
\hline Cement in $\mathrm{kg} / \mathrm{m}^{3}$ & 360 & 285 \\
\hline Fly ash in $\mathrm{kg} / \mathrm{m}^{3}$ & - & 94 \\
\hline Water in $\mathrm{kg} / \mathrm{m}^{3}$ & 180 & 162 \\
\hline $\mathrm{w} / \mathrm{c}_{\mathrm{eq}}{ }^{1}$ & \multicolumn{2}{|c|}{0.50} \\
\hline Aggregate in $\mathrm{kg} / \mathrm{m}^{3}$ & 1801 & 1799 \\
\hline Grading curve & \multicolumn{2}{|c|}{ C8 (DIN 1045 - 2) } \\
\hline
\end{tabular}

${ }_{1} \mathrm{w} / \mathrm{c}_{\mathrm{eq}}=\mathrm{w} /(\mathrm{c}+\mathrm{k} \cdot \mathrm{f})$ with $\mathrm{k}=0.4, \mathrm{f} \ldots$ fly ash content.

A PCE superplasticizer was used to achieve an equal flow of 180 to $220 \mathrm{~mm}$ in accordance to EN 1015-3. The air void content was tested according to EN 1015-7. For each mixture 24 concrete specimen according to ASTM C307 as well as 12 prisms $\left(40 \times 40 \times 160 \mathrm{~mm}^{3}\right.$, EN 196-1) were casted and stored at $20^{\circ} \mathrm{C}$ and $90 \%$ relative humidity for $24 \mathrm{~h}$ before demolding. Afterwards the specimens were cured in saturated $\mathrm{Ca}(\mathrm{OH})_{2}$-solution at $20{ }^{\circ} \mathrm{C}$ until an age of 28 days.

After $\mathrm{Ca}(\mathrm{OH})_{2}$ curing the specimens were placed in a sodium sulfate solution with $6000 \mathrm{mg} \mathrm{SO}_{4}{ }^{2-} / \mathrm{L}$ at $5{ }^{\circ} \mathrm{C}$ until testing. The sulfate solution was renewed every 7 days until 28 days of storage and every 14 days subsequently.

\subsubsection{Strength Testing of Specimens Stored in Sulfate Solutions}

The tensile strength of the briquet specimens and the flexural strength of the prism samples were measured after 119, 182 and 273 days of storage in the sulfate solution in saturated surface dry condition. As reference the strength after 28 days curing was determined. The tensile strength of six briquet specimens for each testing age was determined according to ASTM C307 using a universal testing machine Zwick ZMART.Pro with a $10 \mathrm{kN}$ load cell. The machine was operated path-controlled with a speed of $5 \mathrm{~mm} / \mathrm{min}$. To measure the flexural strength a testing machine Form + Test with a $10 \mathrm{kN}$ load cell was used. The machine was operated in accordance with EN 196-1.

\subsubsection{Thermodynamic Validation}

One objective of the development of the test method was to ensure that the chosen experimental approach is close to field conditions. The major driving force of sulfate induced damage is the occurrence of crystallization pressure within the attacked sample. 
Hence thermodynamic calculations are an appropriate tool to compare the crystallization pressure within the damaged zone of the accelerated test specimens to naturally conditioned samples at elevated sulfate concentrations. Here we adopt the approach by Flatt and Scherer to calculate crystallization pressure caused by delayed ettringite formation [29]. The crystallization pressure that is able to damage the concrete matrix is equivalent to the average hydrostatic tensile stress in the solid and can be expressed as:

$$
\sigma=\sigma_{C} g\left(\phi_{C}\right)
$$

where

- $\sigma_{\mathrm{C}}$ is the pressure needed to suppress the growth of a crystal in a supersaturated solution,

- $\quad \phi_{C}$ is the volume fraction of the crystals exerting pressure.

For a cylindrical pore $\mathrm{g}\left(\phi_{\mathrm{C}}\right)$ can be calculated by

$$
\mathrm{g}\left(\phi_{\mathrm{C}}\right)=\frac{2}{3}\left(\frac{\phi_{\mathrm{C}}}{1-\phi_{\mathrm{C}}}\right)
$$

For a filled large spherical pore with small entries, it is given by

$$
\mathrm{g}\left(\phi_{\mathrm{C}}\right)=\left(\frac{\phi_{\mathrm{C}}}{1-\phi_{\mathrm{C}}}\right)
$$

The strength of the surrounding matrix needed to suppress the growth of a crystal, e.g., ettringite or gypsum, in a supersaturated solution is defined as follows:

$$
\sigma_{\mathrm{C}}=\frac{\mathrm{R}_{\mathrm{g}} \mathrm{T}}{v_{\text {crystal }}} \ln \left(\frac{\mathrm{Q}}{\mathrm{K}}\right)
$$

where

- $\mathrm{R}_{\mathrm{g}}$ is the gas constant $\left(8.3144 \mathrm{~kg} \cdot \mathrm{m}^{2} / \mathrm{s}^{2} \cdot \mathrm{mol} \cdot \mathrm{K}\right)$,

- $\mathrm{T}$ is the absolute temperature in $\mathrm{K}$,

- $v_{\text {crystal }}$ is the molar volume of the crystal in $\mathrm{cm}^{3} / \mathrm{mol}$,

- $\mathrm{Q} / \mathrm{K}$ is the supersaturation,

- $\mathrm{Q}$ is the ion activity product,

- $\mathrm{K}$ is the equilibrium constant.

Using the geochemical calculation tool GEMS [30] and the latest version of the database Cemdata18.1 [31], the amount of ettringite and gypsum able to exert pressure within a hydrated mortar matrix (SVA method) and concrete specimen (performance test) was calculated. The supersaturation with respect to ettringite and gypsum under the different environmental circumstances of the methods was calculated and tested against practical conditions in sulfate containing groundwater in Germany.

\section{Results}

The established test method for sulfate resistance testing in Germany is the measurement of expansion on mortar flat prisms according to the SVA approach. In the study we used this method as state-of-the art reference, followed by a demonstration of results obtained by the novel method based on tensile strength testing. The results will be subsequently compared; including a discussion of advantages and disadvantages of the methods. The underlying original data of this study is provided in the Supplementary Materials.

\subsection{SVA Method}

As described in the introduction, the storage of the specimen in the SVA test method was originally done at $30,000 \mathrm{mg} \mathrm{SO}{ }^{2-} / \mathrm{L}$ using a sodium sulfate solution at $20{ }^{\circ} \mathrm{C}$. Exemplary results of these tests are shown in Figure 1 (left) for selected binder types used 
in this study. The indicated threshold values of 0.5 and $0.8 \mathrm{~mm} / \mathrm{m}$ apply for storage times of 91 and 180 days, respectively.
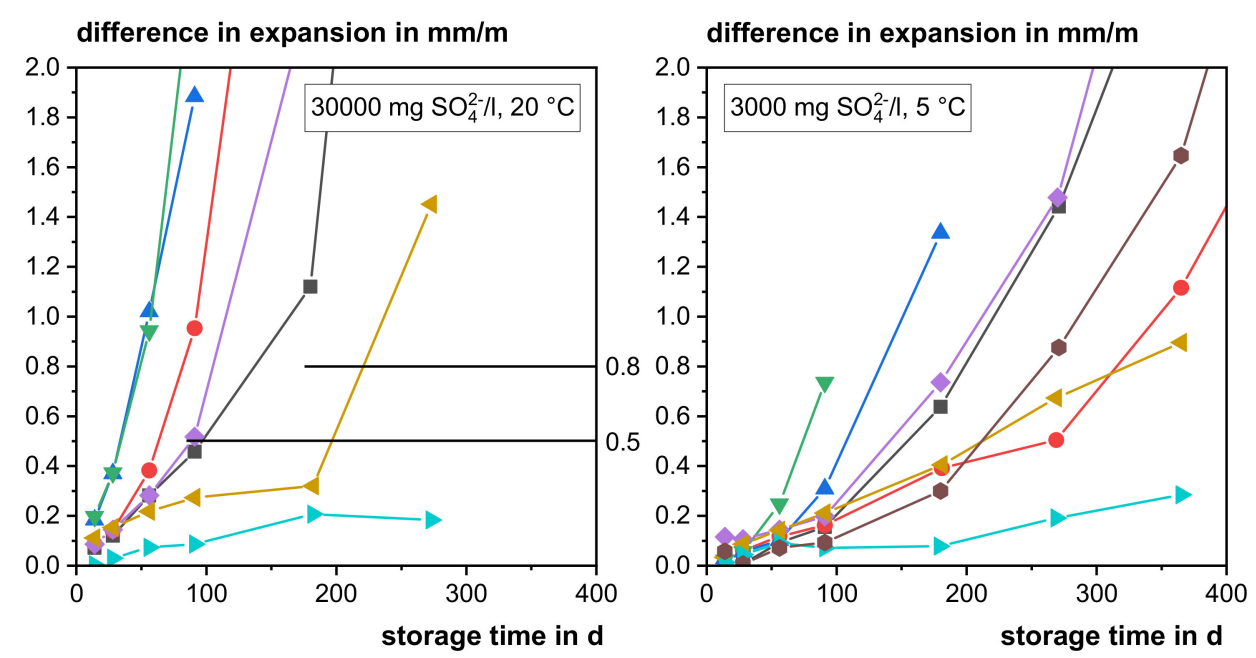

\begin{tabular}{|lll|}
\hline$-\square-(2)$ CEM I 42.5 N & -- (5) CEM I 42.5 N-SR3 & $-\triangle-$ (19) CEM II/A-LL 42.5 N \\
$-\nabla-$ (7) CEM II/A-S 42.5 N & - (10) CEM III/A 42.5 N & - - (11) CEM III/A 42.5 N SR \\
-- (13) CEM III/B 42.5 N LH/SR & -- (21) CEM I 42.5 N + SFA 1 \\
\hline
\end{tabular}

Figure 1. Exemplary results for the difference in expansion over time determined by the SVA test method: $30,000 \mathrm{mg} \mathrm{SO}{ }^{2-} / \mathrm{L}$ and $20^{\circ} \mathrm{C}$ (left) and $3000 \mathrm{mg} \mathrm{SO}_{4}{ }^{2-} / \mathrm{L}$ at $5{ }^{\circ} \mathrm{C}$ (right).

After 91 days three of the binders, the (2) CEM I $42.5 \mathrm{~N}$, the (17) CEM III/A $42.5 \mathrm{~N}$ SR and the (19) CEM III/B $42.5 \mathrm{~N} \mathrm{LH} / \mathrm{SR}$, still comply with the threshold of $0.5 \mathrm{~mm} / \mathrm{m}$ at $20{ }^{\circ} \mathrm{C}$. The expansion for the samples with blastfurnace slag cement (15) CEM III/A $42.5 \mathrm{~N}$ without attested sulfate resistance is just slightly above the limit value. After storage for another 90 days only the two blastfurnace slag cements still comply with the defined limit of $0.8 \mathrm{~mm} / \mathrm{m}$. Remarkably the samples with sulfate resistant Portland cement (5) CEM I 42.5 N-SR3 do not fulfill the maximum threshold values and show even higher expansions than the ordinary Portland cement (2) CEM I 42.5 N. This phenomenon has been frequently observed in laboratory tests in recent years [21,32]. For the mortar flat prisms with Portland limestone cement and (13) CEM II/A-S $42.5 \mathrm{~N}$ no sulfate resistance can be expected, they show extensive expansion during this test. Due to an error, no data was collected for the combination of CEM I with fly ash under these storage conditions.

Additionally, results of storage at $3000 \mathrm{mg} \mathrm{SO} 4^{2-} / \mathrm{L}$ at $5{ }^{\circ} \mathrm{C}$ are shown in the diagram on the right. Testing at these storage conditions has been demanded by the expert committee during recent years because of predominant formation of gypsum at a concentration level of $30,000 \mathrm{mg} \mathrm{SO}_{4}{ }^{2-} / \mathrm{L}$. Again, the lowest expansion can be observed for the (17) CEM III/A 42.5 N SR and the (19) CEM III/B $42.5 \mathrm{~N} \mathrm{LH/SR,} \mathrm{the} \mathrm{highest} \mathrm{for} \mathrm{the}$ Portland composite cements (CEM II). In contrast to storage at $30,000 \mathrm{mg} \mathrm{SO}{ }^{2-} / \mathrm{L}$ at $20{ }^{\circ} \mathrm{C}$ the sulfate resistant (5) CEM I $42.5 \mathrm{~N}-\mathrm{SR} 3$ shows less expansion than the (2) CEM I $42.5 \mathrm{~N}$, which is in the range of the blastfurnace slag cement (15) CEM III/A $42.5 \mathrm{~N}$. The expansion of the samples with CEM I and fly ash is in the middle between these binders.

It can be concluded, that the storage at $3000 \mathrm{mg} \mathrm{SO}{ }^{2-} / \mathrm{L}$ at $5{ }^{\circ} \mathrm{C}$, as has been shown previously [32], leads to a different mechanism and the precipitation of ettringite instead of gypsum is the dominant expansive force. However, no threshold values are provided for these storage conditions, and the necessary test duration was extended to two years of storage, which is typically too long for compliance testing.

\subsection{Performance Test Based on Tensile Strength Measurements}

Figure 2 shows the results of the newly developed tensile strength test using concretes based on 23 different binders over the course of 273 days. After 119 days concrete with (1) CEM I 32.5 R and (3) CEM I $42.5 \mathrm{R}$ as well as all Portland composite cements except 
(14) CEM II/B-S $42.5 \mathrm{~N}$ already show a large strength loss. After 182 days of storage the differences between the mixtures become even more evident.

rel. tensile strength $f_{t} / f_{t m}$

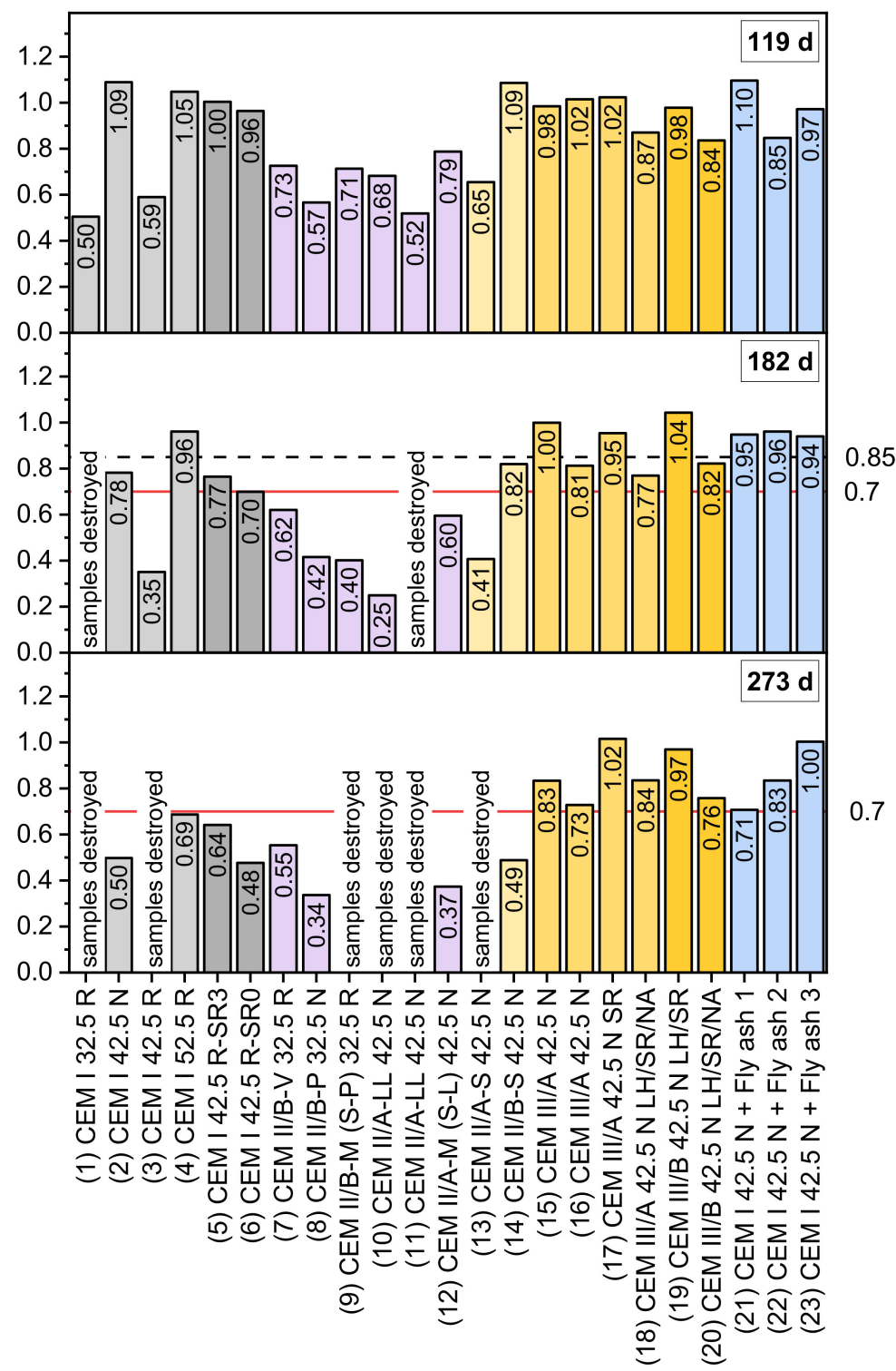

Figure 2. Relative tensile strength $\mathrm{f}_{\mathrm{t}} / \mathrm{f}_{\mathrm{tm}}$ of concrete with 23 different binders after 119,182 and 273 days (grey: Portland cement, purple: CEM II, yellow: slag cement, blue: Portland cement + fly ash; average coefficients of variance: $\sigma_{119 \mathrm{~d}}=9.4 \%, \sigma_{182 \mathrm{~d}}=10.2 \%, \sigma_{273 \mathrm{~d}}=12.3 \%$ ).

Concrete with (4) CEM I 52.5 R has the highest remaining strength compared to the other CEM I, which is probably caused by the higher density due to the high fineness of the cement. Sulfate resistant Portland cements experience a strength loss of about $25 \%$ between 119 and 182 days of storage. Concrete produced with blastfurnace slag cements (CEM III) as well as mixtures of Portland cement with fly ash are the least affected until half a year of storage in the sulfate solution.

After 9 months of storage the relative tensile strength of six mixtures (see Figure 2) could not be determined, because the samples were deteriorated. The spread of the results is the largest, ranging from apparently unaffected concrete mixtures with CEM III/ A, CEM III/B and CEM I + fly ash with a relative tensile strength of 0.97 to 1.02 to mixtures with Portland composite cement (CEM II) and CEM I that showed a low remaining strength of 0 to $55 \%$. 
Based on these results threshold values can be derived as a benchmark for sulfate resistance of the tested concrete. We propose a threshold value of 0.70 for the remaining relative tensile strength after 273 days of storage, which must be achieved or exceeded to demonstrate the capability of a concrete mixture to resist sulfate attack in the field. Based on the obtained data the threshold of 0.70 after 273 days results in a statistical test power $(1-\beta)$ of $0.988(\alpha=0.05, \mathrm{n}=6)$. If concrete mixtures exhibit a relative remaining tensile strength below 0.70 already after a storage of 182 days, the performance test can be stopped $((1-\beta)=0.999)$. On the other hand, concrete mixtures with a remaining relative strength above 0.85 after 182 days $((1-\beta)=0.765)$ will most likely comply with the limit value of 0.70 after $273 \mathrm{~d}$, so they could be considered capable to serve well in a sulfate-rich environment and the test could be stopped after half a year. Concrete mixtures which do not fall into these two categories should be evaluated after 273 days.

Notably, the two Portland cements labeled as sulfate resistant fail the proposed tensile strength test as well as the SVA expansion test. In case of the (6) CEM I 42.5 R-SR0/NA this is most likely caused by the amount of $\mathrm{C}_{3} \mathrm{~A}(5.3 \mathrm{wt} \%)$ in the cement (determined by XRD) despite the label "SR0". The (5) CEM I $42.5 \mathrm{~N}-\mathrm{SR} 3$ contains $3.0 \mathrm{wt} \% \mathrm{C}_{3} \mathrm{~A}$, which is possibly still enough to cause damaging reactions.

\subsection{New Performance Test Method vs. SVA Method}

Since the concrete mix design was similar for the 23 mixtures, the results can be compared to those obtained by the SVA method, which is designed to be a binder test. Figure 3 shows the difference in expansion determined by the SVA method, when stored in $3000 \mathrm{mg} \mathrm{SO}_{4}{ }^{2-} / \mathrm{L}$ at $5{ }^{\circ} \mathrm{C}$, over the remaining relative tensile strength after six months of storage. Linear fits were calculated for the expansion after 56, 91, 182, 271 and 365 days and the relative strength. It is apparent, that a higher expansion is accompanied by a lower remaining strength, as can be expected. This effect becomes more pronounced with increasing test duration. However, no correlations could be determined, as is reflected by the low coefficients of correlation $\mathrm{R}^{2}$. For the relative tensile strength after 273 days (Figure 4 ) the observed trends become weaker because of a smaller sample size and the higher diversification of the results. The shift to lower relative strengths flattens the linear fits. They agglomerate at an expansion close to zero and a relative strength of about 1.0, indicating the region for highly durable binders (SVA method) and concrete (tensile strength test).

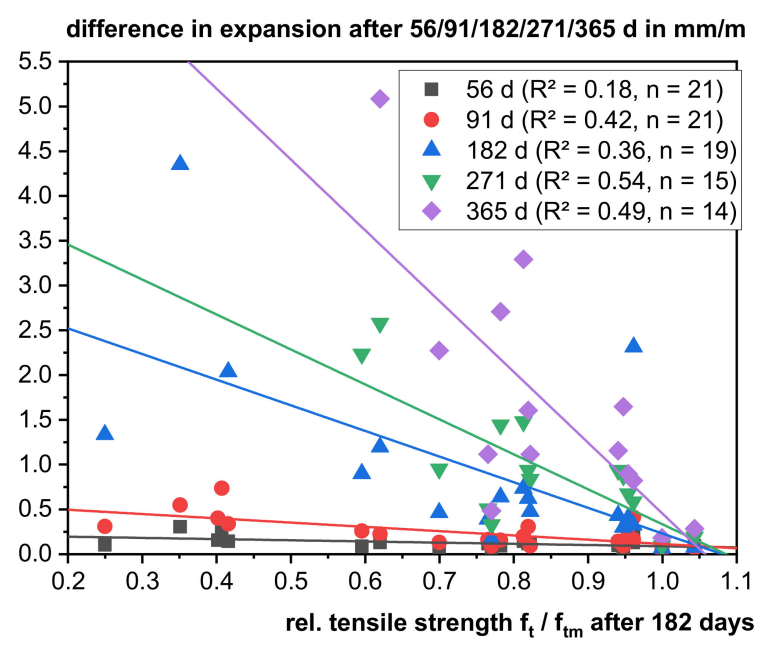

Figure 3. Correlation of the difference in expansion (SVA method, $3000 \mathrm{mg} \mathrm{SO}_{4}{ }^{2-} / \mathrm{L}, 5{ }^{\circ} \mathrm{C}$ ) over the course of time (see colored markers and lines) and the relative tensile strength $f_{t} / f_{t m}$ after 182 days. 


\section{difference in expansion after 56/91/182/271/365 d in $\mathrm{mm} / \mathrm{m}$}

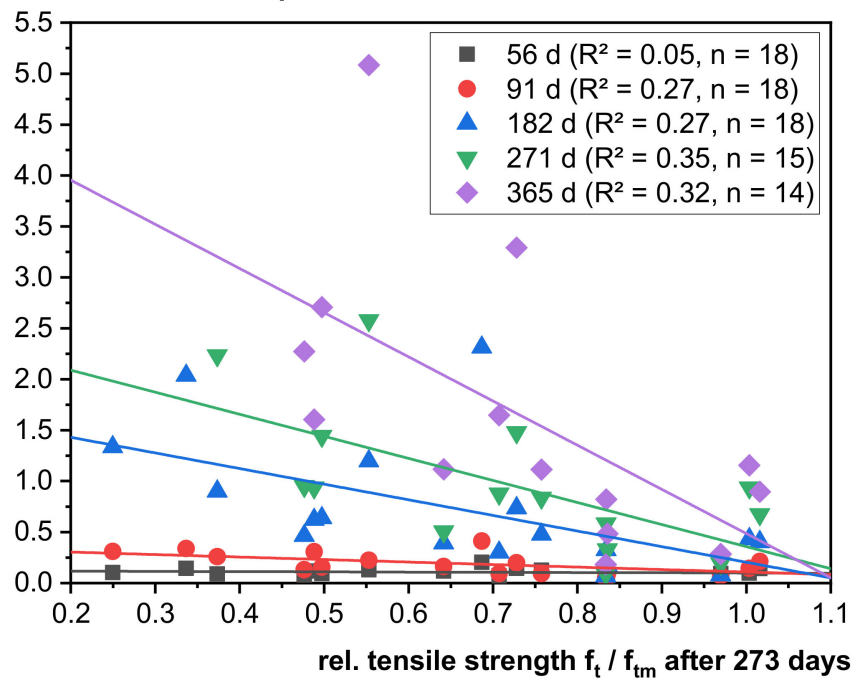

Figure 4. Correlation of the difference in expansion (SVA method, $3000 \mathrm{mg} \mathrm{SO}_{4}{ }^{2-} / \mathrm{L}, 5{ }^{\circ} \mathrm{C}$ ) over the course of time and the relative tensile strength $\mathrm{f}_{\mathrm{t}} / \mathrm{f}_{\mathrm{tm}}$ after 273 days.

Storage in sodium sulfate solution with $30,000 \mathrm{mg} \mathrm{SO}_{4}{ }^{2-} / \mathrm{L}$ at $20{ }^{\circ} \mathrm{C}$ is the original environment used to determine the sulfate resistance of cement in the SVA test method. The high sulfate concentration results in a predominant formation of gypsum and earlier destruction of the samples. That leads to a smaller number of remaining samples available for the calculation of the linear correlations at longer testing ages. The respective results are presented in Figures 5 and 6 for the relative tensile strength after 182 and 273 days, respectively. After 56 and 91 days a strong trend can be observed, but no correlation could be found for the expansion after 182 days storage. Due to the very different storage conditions of the test methods, the arrangement of the fits is not staggered in a way as could be observed in Figures 3 and 4 for storage expansion after storage in $3000 \mathrm{mg} \mathrm{SO}_{4}{ }^{2-} / \mathrm{L}$ at $5{ }^{\circ} \mathrm{C}$.

difference in expansion after $56 / 91 / 182 \mathrm{~d}$ in $\mathrm{mm} / \mathrm{m}$



Figure 5. Correlation of the difference in expansion (SVA method, 30,000 $\mathrm{mg} \mathrm{SO}_{4}{ }^{2-} / \mathrm{L}, 20{ }^{\circ} \mathrm{C}$ ) over the course of time and the relative tensile strength $\mathrm{f}_{\mathrm{t}} / \mathrm{f}_{\mathrm{tm}}$ after 182 days. 
difference in expansion after 56/91/182 d in $\mathrm{mm} / \mathrm{m}$

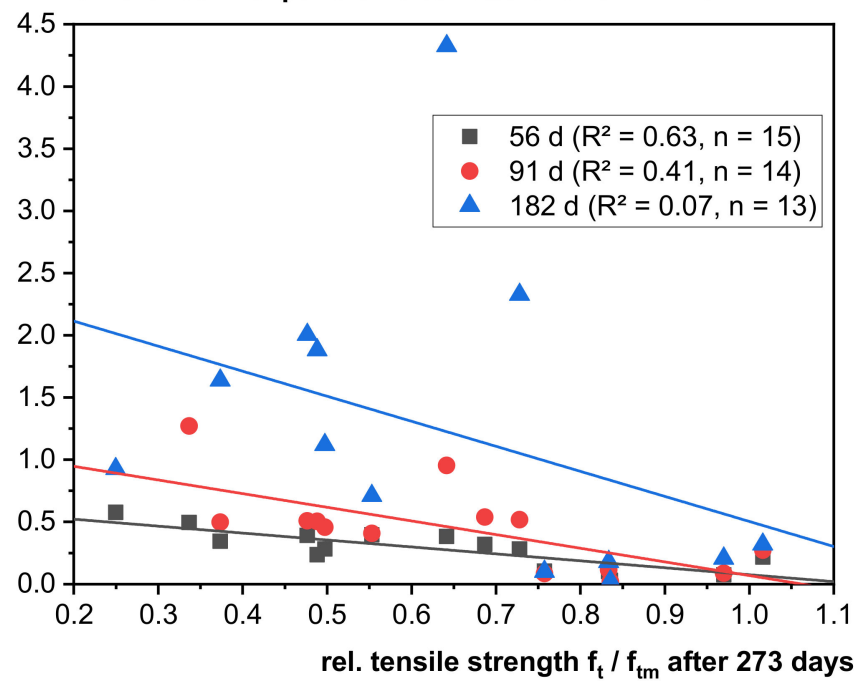

Figure 6. Correlation of the difference in expansion (SVA method, 30,000 $\mathrm{mg} \mathrm{SO}_{4}{ }^{2-} / \mathrm{L}, 20{ }^{\circ} \mathrm{C}$ ) over the course of time and the relative tensile strength $f_{t} / f_{t m}$ after 273 days.

It can be concluded that the determination of the difference in expansion (SVA method) is able to identify binders with a high resistance to sodium sulfate attack (blastfurnace slag cements CEM III). The newly developed method additionally allows to evaluate the impact of mix design and the resulting pore structure on sulfate resistance of concrete (binder and composition).

To emphasize the difference of the newly developed performance test in comparison to the established SVA method, Figure 7 shows an excerpt from results for expansion measurements after storage for 91 and 182 days in $30,000 \mathrm{mg} \mathrm{SO}{ }_{4}{ }^{2-} / \mathrm{L}$ at $20{ }^{\circ} \mathrm{C}$ over the relative tensile strength determined according to the newly developed method after 273 days. That way, the threshold values of the original SVA method $(0.5 \mathrm{~mm} / \mathrm{m}$ after 91 days and $0.8 \mathrm{~mm} / \mathrm{m}$ after 182 days) as well as the proposed minimum relative tensile strength of 0.70 after 273 days can be indicated.

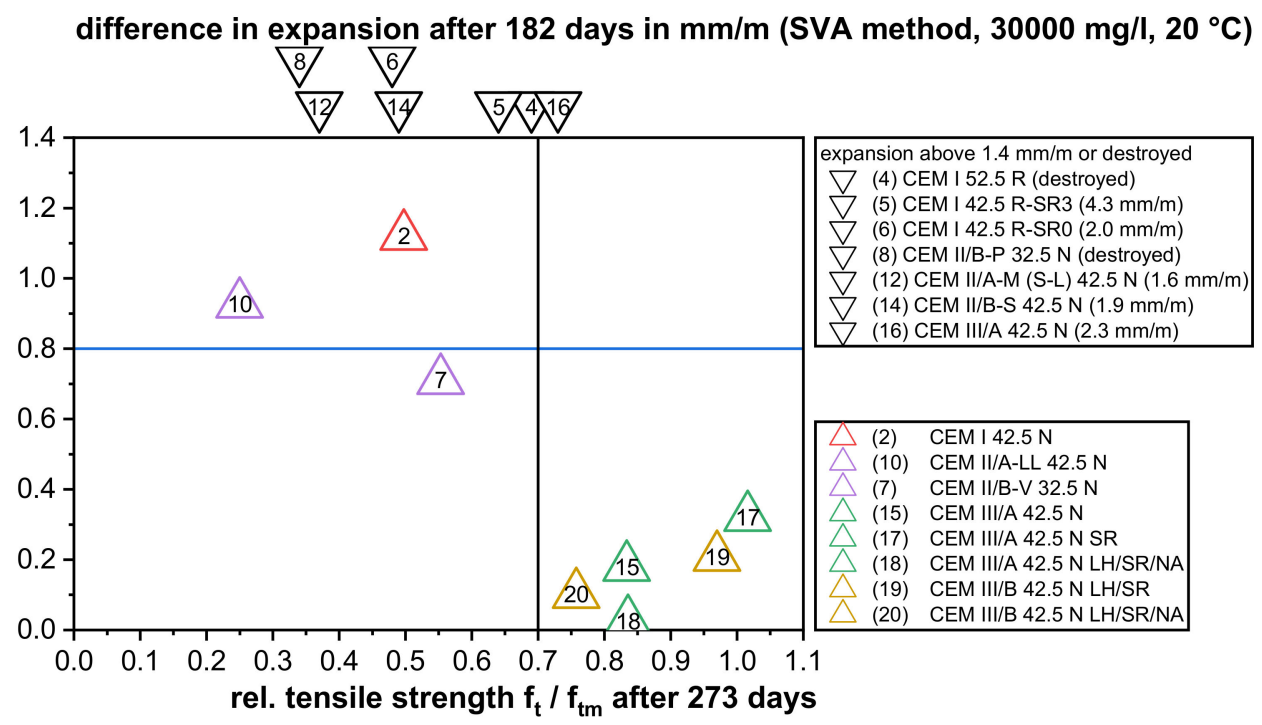

Figure 7. Difference in expansion (SVA method, 30,000 $\mathrm{mg} \mathrm{SO}_{4}{ }^{2-} / \mathrm{L}, 2{ }^{\circ} \mathrm{C}$ ) after 182 days over the relative tensile strength $f_{t} / f_{t m}$ after 273 days.

All blastfurnace slag cements as well as the (7) CEM II/B-V with fly ash as additional constituent comply with both SVA threshold values. Most of those cements also satisfy the proposed threshold for the relative tensile strength after 273 days-the (7) CEM II/B-V 
being an exception at a remaining tensile strength of 0.55 . CEM III/ A $42.5 \mathrm{~N}$ (cement 15) lies narrowly within the threshold for the tensile strength but exceeds the thresholds of the original flat prism test. Mortar and concrete with any other binders included in the investigations did not meet the requirements with both test methods.

The graph clearly illustrates that only blastfurnace cements are found in the range of low expansion and high relative residual tensile strengths. Interestingly, their $\mathrm{C}_{3} \mathrm{~A}$ content correlates independently of the blastfurnace slag content with the relative tensile strength remaining after 273 days of sulfate storage $\left(R^{2}=0.83, n=6\right.$, cf. Figure 8 (left)). The highest remaining strength after 273 days was observed for the cements with the lowest $\mathrm{C}_{3} \mathrm{~A}$ content. This indicates that the major cause of deterioration during storage in the sulfate solution with $6000 \mathrm{mg} \mathrm{SO}{ }_{4}{ }^{2-} / \mathrm{L}$ at $5{ }^{\circ} \mathrm{C}$ is the formation of ettringite from $\mathrm{C}_{3} \mathrm{~A}$, not the formation of gypsum, which is the case during testing with the SVA method at $30,000 \mathrm{mg} \mathrm{SO}_{4}{ }^{2-} / \mathrm{L}$. No correlation could be found for the residual strength and the content of blastfurnace slag or the $\mathrm{Al}_{2} \mathrm{O}_{3}$ content available for reaction. There is also no general correlation between the relative tensile strength and the $\mathrm{C}_{3} \mathrm{~A}$ content of cements, when the type of cement is not taken into consideration. Similarly, there is no comparable correlation with the measured expansion in the SVA method.
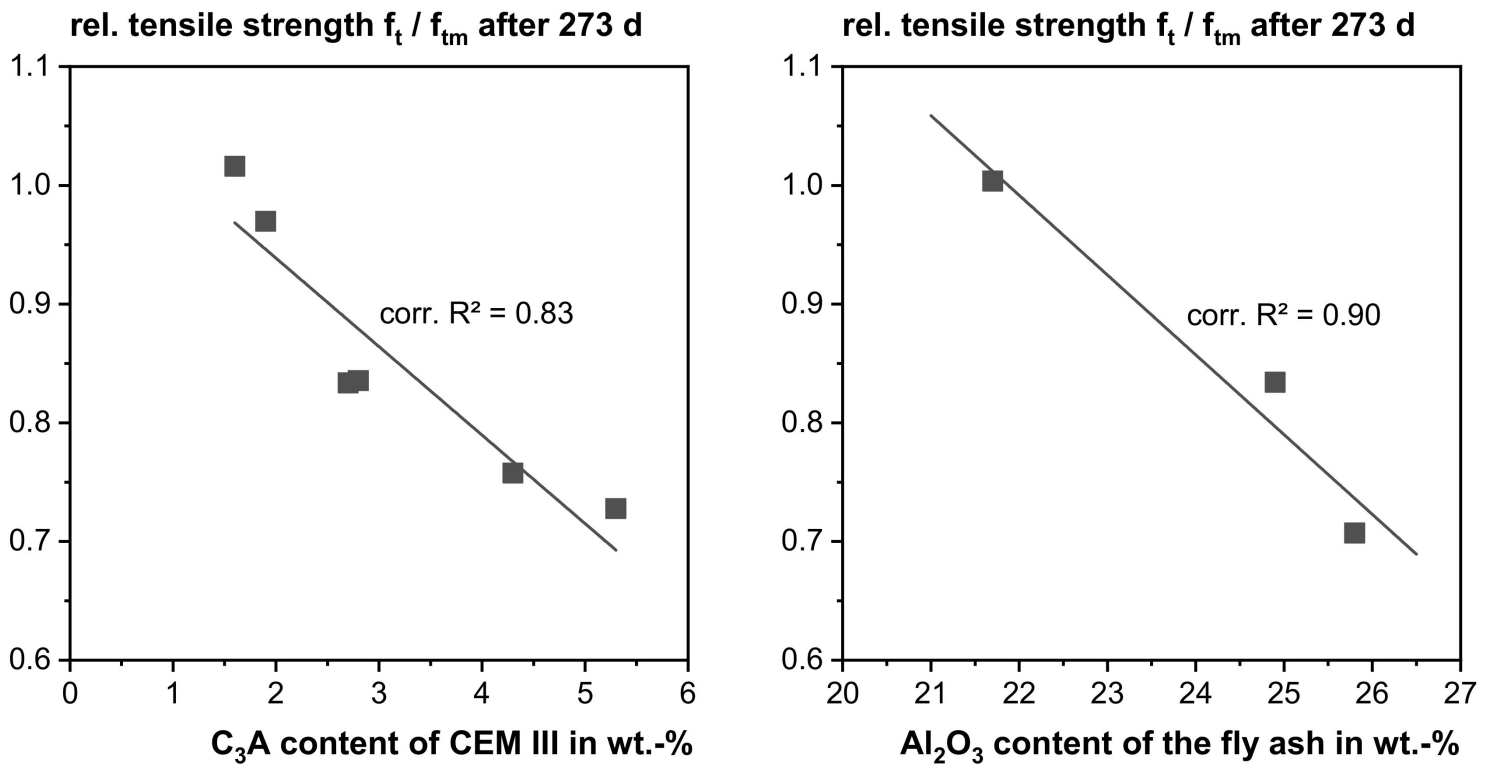

Figure 8. Relative tensile strength after $273 \mathrm{~d}$ storage in $6000 \mathrm{mg} \mathrm{SO}_{4}{ }^{2-} / \mathrm{L}$ at $5{ }^{\circ} \mathrm{C}$ over the $\mathrm{C}_{3} \mathrm{~A}$ content of blastfurnace slag cement (CEM III) (left) and the $\mathrm{Al}_{2} \mathrm{O}_{3}$ content of fly ash (right).

The modified SVA method requires a 2-year (730d) storage in a sodium sulfate solution with $3000 \mathrm{mg} \mathrm{SO}_{4}{ }^{2-} / \mathrm{L}$ at $5{ }^{\circ} \mathrm{C}$. However, since a large number of mortars were destroyed after 365 days the difference in expansion after 365 days of storage was plotted against the relative tensile strength after 273 days in Figure 9. No correlation could be found for the expansion under these conditions and the $\mathrm{C}_{3} \mathrm{~A}$ content of the blastfurnace cements. However, there seems to be a similar negative influence of the $\mathrm{Al}_{2} \mathrm{O}_{3}$ content of the fly ash on the residual tensile strength (see Figure 8 (right)). Due to the small amount of fly ashes included in the test program, the effect should be taken cautiously and undergo further investigation.

Figure 9 illustrates the advantage of the performance test method: the concrete recipe is evaluated in addition to the binder. For concrete with (14) CEM II/B-S $42.5 \mathrm{~N}$, an otherwise unchanged batch with a lower water content $(\mathrm{w} / \mathrm{c}=0.45)$ was tested in a previous study [25]. The densification of the matrix achieved by the lower water/cement ratio resulted in a $65 \%$ increase of the remaining relative strength after 273 days from 0.49 to 0.81 . The modified concrete thus met the proposed limit value of 0.70 and should therefore have a high sulfate resistance. This concrete demonstrates representatively for 
others that with the test method it is generally possible to compensate for a lower chemical resistance to sulfate attack by a higher physical resistance of the concrete-the basic idea of a performance test method.

difference in expansion after 365 days in $\mathrm{mm} / \mathrm{m}$ (SVA method, $3000 \mathrm{mg} / \mathrm{l}, 5^{\circ} \mathrm{C}$ )

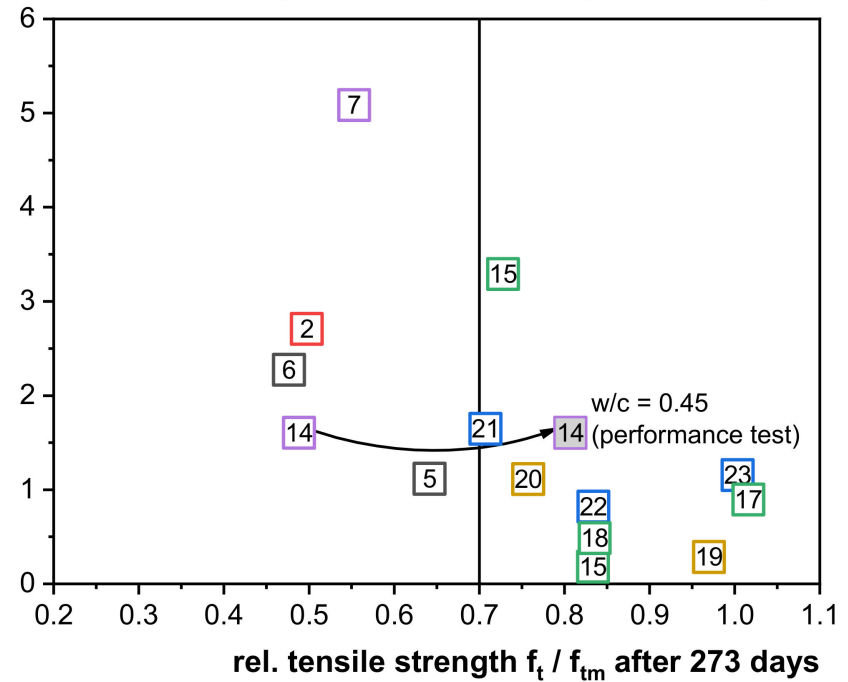

$$
\begin{array}{|ll|}
\hline \text { (2) } & \text { CEM I 42.5 N } \\
\text { (5) } & \text { CEM I 42.5 R SR3 NA } \\
(6) & \text { CEM I 42.5 R SRO/NA } \\
(7) & \text { CEM II/B-V 32.5 R } \\
(14) & \text { CEM II/B-S 42.5 N } \\
(15) & \text { CEM III//A 42.5 N } \\
(16) & \text { CEM III/A 42.5 N } \\
(17) & \text { CEM III/A 42.5 N SR } \\
(18) & \text { CEM III/A 42.5 N LH/SR/NA } \\
(19) & \text { CEM III/B 42.5 N LH/SR } \\
(20) & \text { CEM III/B 42.5 N LH/SR/NA } \\
(21) & \text { CEM I 42.5 N + SFA } 1 \\
(22) & \text { CEM I 42.5 N + SFA 2 } \\
(23) & \text { CEM I 42.5 N + SFA 3 } \\
\hline
\end{array}
$$

Figure 9. Difference in expansion (SVA method, $3000 \mathrm{mg} \mathrm{SO}_{4}{ }^{2-} / \mathrm{L}, 5^{\circ} \mathrm{C}$ ) after 365 days over the relative tensile strength $f_{t} / f_{t m}$ after 273 days.

\subsection{Reproducibility}

The intra-lab reproducibility of the test method was evaluated. Five additional batches of concrete with (2) CEM I $42.5 \mathrm{~N}$ were prepared and 6 briquet specimen were tested for each batch after 119, 182 and 273 days of storage in $6000 \mathrm{mg} \mathrm{SO}_{4}{ }^{2-} / \mathrm{L}$ sodium sulfate solution at $5{ }^{\circ} \mathrm{C}$. The results are shown in Figure 10. The average tensile strength is $0.940 \pm 0.100$ after 119 days, $0.723 \pm 0.066$ after 182 days and $0.528 \pm 0.075$ after 273 days For half of the mixtures the test could be terminated after 182 days according to the proposed thresholds. After 273 days all six mixtures fail the threshold of a remaining relative strength of $70 \%$. The coefficient of variation is $10.6 \%$ and $9.2 \%$ after 119 and 182 days, respectively, and increases to $14.1 \%$ after 273 days of storage. This larger relative diversification can be attributed to the ongoing deterioration of the samples and the associated higher scatter of the tensile strength.

rel. tensile strength $f_{t} / f_{t m}$

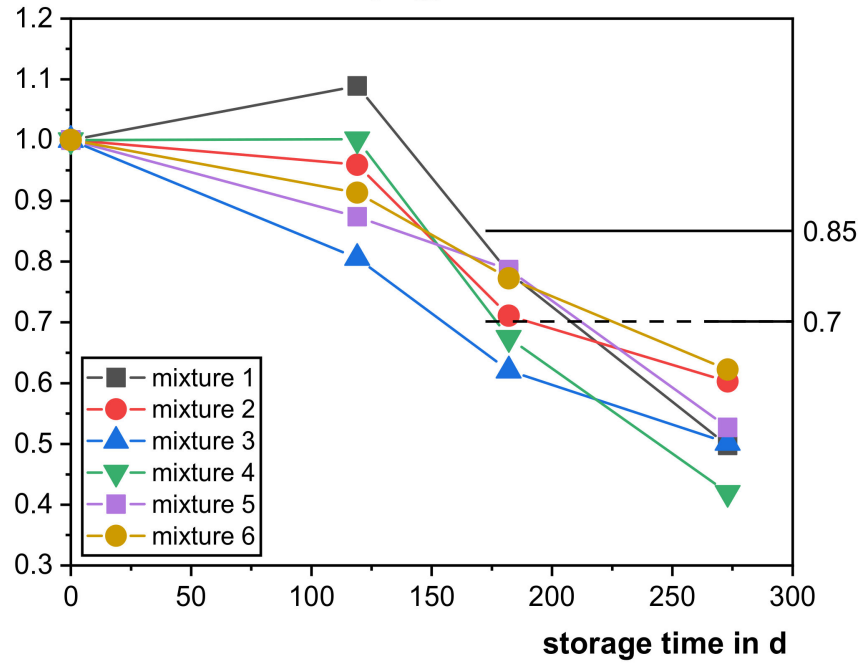

Figure 10. Relative tensile strength $\mathrm{f}_{\mathrm{t}} / \mathrm{f}_{\mathrm{tm}}$ of six identic concrete mixtures with (2) CEM I $42.5 \mathrm{~N}$ after 119,182 and 273 days. 
The graph emphasizes that after 119 days of storage the test setup is not able to predict the sulfate resistance of a concrete mixture. The coefficient of variation is low enough to achieve meaningful results for non-sulfate resistant concrete mixtures potentially after 182 and with certainty after 273 days of storage. Increasing the number of samples would be an option to decrease the coefficient of variation, increase the statistical power $(1-\beta)$ of the test method and thereby allow for a more precise prediction of the sulfate resistance of a concrete mixture.

\subsection{Validation by Thermodynamic Calculations}

Basic criticism of the SVA method, which was originally done with mortar flat prisms at $20^{\circ} \mathrm{C}$ exposed to a sodium sulfate solution with $30,000 \mathrm{mg} \mathrm{SO}_{4}{ }^{2-} / \mathrm{L}$, is the different attack mechanism due to the excessive formation of gypsum, especially in calcium hydroxide rich cements, compared to what can be observed in practice. Additionally, the test utilizes standard sand in cement mortar according to EN 196-1, which provides a very different microstructure compared to the microstructure of concrete produced with a larger amount of aggregate with a wider grain size distribution.

This section discusses the different environmental conditions of the SVA method and the newly developed performance test method and examines the thermodynamic processes that affect the outcome. The calculations are exemplarily presented for Portland cement (2) CEM I $42.5 \mathrm{~N}$ (cf. Tables 2 and 4).

In a first step the amount of ettringite and gypsum after pre-storage for 28 days at $20{ }^{\circ} \mathrm{C}$ before immersion in the sulfate solution was calculated with help of mass balance calculations using GEMS-PSI. The kinetic parameters are based on the Parrot and Killoh model [33]. The degree of hydration for the clinker minerals were assumed as follows: $\mathrm{C}_{3} \mathrm{~S}$ $88 \%, \mathrm{C}_{3} \mathrm{~A} 100 \%, \mathrm{C}_{4} \mathrm{AF} 81 \%$ and $\mathrm{C}_{2} \mathrm{~S} 56 \%$. The resulting mass and volume balances are shown in Table 7.

Table 7. Mass and volume balance of cement paste/mortar/concrete normalized to $100 \mathrm{~g}$ (2) CEM I $42.5 \mathrm{~N}$ plus aggregates after $28 \mathrm{~d}$ hydration, assuming equilibrium conditions in the SVA method at $30 \mathrm{~g} \mathrm{SO}_{4}{ }^{2-} / \mathrm{L}$ and $20{ }^{\circ} \mathrm{C}$, and in the new performance test at $6 \mathrm{~g} \mathrm{SO}_{4}{ }^{2-} / \mathrm{L}$ at $5{ }^{\circ} \mathrm{C}$.

\begin{tabular}{|c|c|c|c|c|c|c|}
\hline \multirow[t]{2}{*}{ Phase } & \multicolumn{2}{|c|}{$\begin{array}{l}\text { (2) CEM I } 42.5 \mathrm{~N} \text {, } \\
28 \text { d Hydration } \\
\text { (Cement Paste) }\end{array}$} & \multicolumn{2}{|c|}{$\begin{array}{c}\text { SVA Method, } \\
30 \mathrm{~g} / \mathrm{L}, 20^{\circ} \mathrm{C} \\
\text { (mortar, EN 196-1) }\end{array}$} & \multicolumn{2}{|c|}{$\begin{array}{c}\text { Performance Test, } \\
6 \mathrm{~g} / \mathrm{L}, 5^{\circ} \mathrm{C} \\
\text { (Concrete, cf. Table 6) }\end{array}$} \\
\hline & Volume $\left[\mathrm{cm}^{3}\right]$ & Mass [g] & Volume $\left[\mathrm{cm}^{3}\right]$ & Mass [g] & Volume $\left[\mathrm{cm}^{3}\right]$ & Mass [g] \\
\hline $\mathrm{C}_{3}(\mathrm{AF}) \mathrm{S}_{0.84} \mathrm{H}$ & 2.82 & 8.32 & - & - & - & - \\
\hline CSHQ & 23.22 & 52.32 & 23.20 & 52.94 & 22.35 & 51.31 \\
\hline Ettringite & 11.64 & 20.64 & 35.44 & 63.34 & 35.44 & 63.34 \\
\hline $\mathrm{C}_{4} \mathrm{AcH}_{11}$ & 3.68 & 7.98 & - & - & - & - \\
\hline Calcite & 1.45 & 3.92 & 2.15 & 5.84 & 2.16 & 5.85 \\
\hline Portlandite & 10.99 & 24.63 & - & - & - & - \\
\hline Gypsum & - & - & 10.93 & 25.19 & 3.92 & 9.04 \\
\hline Aggregate & - & - & 113.21 & 300.00 & 188.68 & 500.00 \\
\hline
\end{tabular}

Both experimental setups (SVA \& performance test) use about $3.5 \mathrm{~L}$ of an artificial sulfate solution in which 6 specimens are stored. The ingress of the attacking sulfate solution occurs from the outside of the specimens and does not affect the whole sample in the same way. As an approximation, the first three millimeters from the surface are considered as being severely influenced by the attack [22,32]. Therefore, the actual affected volume is different from the total volume of the specimen (see Figure 11). For mortar flat prisms, we estimate this amount to about $67 \mathrm{vol}-\%$ of the specimen, whereas for the briquet specimen the affected volume is about $41 \%$ of the sample. This is taken into account in the thermodynamic calculations by adjusting the liquid/solid ratio under equilibrium conditions adequately. 

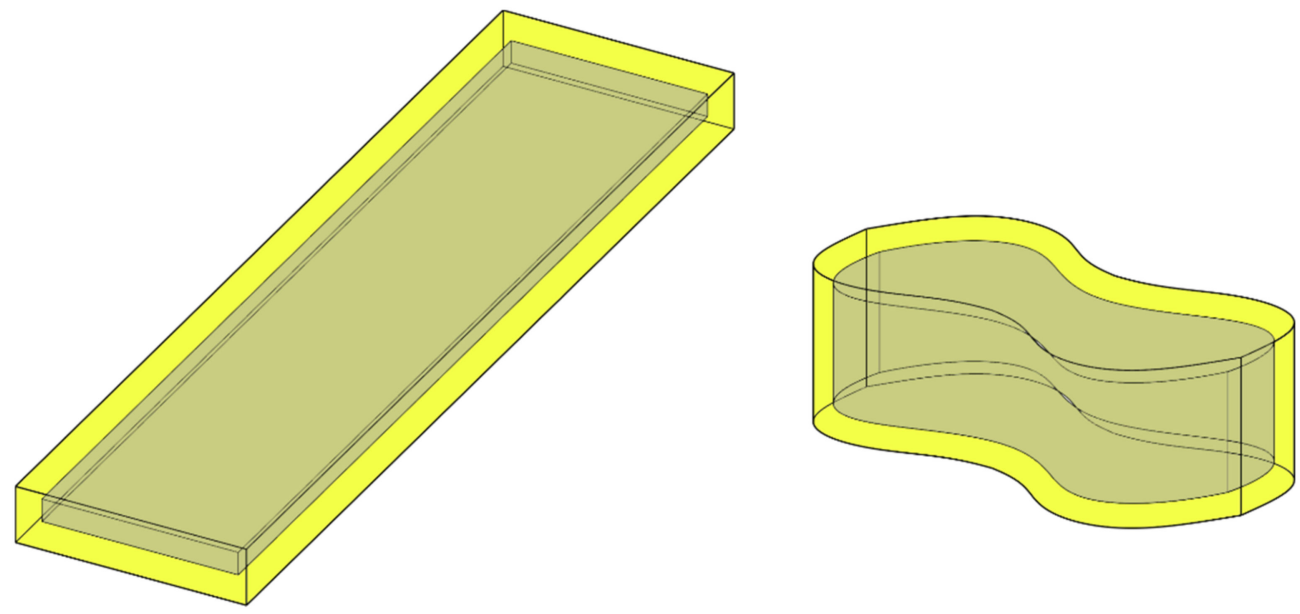

Figure 11. Volume affected by sulfate ingress (yellow, depth: $3 \mathrm{~mm}$ ): mortar flat prism $\left(10 \times 40 \times 160 \mathrm{~mm}^{3}\right.$, SVA method) and briquet specimen (ASTM C307-03); unaffected volume: grey.

To determine the maximum amount of ettringite and gypsum within the damaged specimen section during sulfate storage a new volume balance was calculated after sulfate exposure. In these calculations we neglected the initially formed ettringite after 28 days hydration. The results are displayed in Table 7 for the main phases and show, that for the SVA test 12.9 vol- $\%$ of ettringite and 5.9 vol- $\%$ gypsum are additionally formed, whereas in the concrete specimen of the performance test a maximum amount of $9.4 \mathrm{vol}-\%$ additional ettringite and 1.6 vol- $\%$ gypsum was estimated. It was furthermore found that the volume fraction of the newly formed ettringite and gypsum in the damaged zone exceeds the total initial porosity of the system substantially. Therefore, the influence of the remaining porosity or newly formed cracks on the calculation of the volume fractions of the samples was disregarded.

In addition to the two test scenarios, storage of concrete specimens in a natural groundwater was considered as a reference for field conditions at elevated sulfate concentrations. The groundwater composition taken into account (Table 8) was a sample originating from an anhydrite mine in southern Germany, where currently additional samples are exposed for long-term storage experiments.

Table 8. Composition of sulfate containing groundwater, taken from anhydrite mine in Hüttenheim, Germany in November 2019.

\begin{tabular}{ccccccccc}
\hline Parameter & Unit & Value & Parameter & Unit & Value & Parameter & Unit & Value \\
\hline Temperature & ${ }^{\circ} \mathrm{C}$ & 13.0 & Calcium & $\mathrm{mg} / \mathrm{L}$ & 575 & Sodium & $\mathrm{mg} / \mathrm{L}$ & 47.4 \\
$\mathrm{pH}$ & - & 7.6 & Iron & $\mu \mathrm{g} / \mathrm{L}$ & 5.1 & Nitrate & $\mathrm{mg} / \mathrm{L}$ & 188 \\
Hardness & ${ }^{\circ} \mathrm{dH}$ & $3.9 \mathrm{~L}$ & Magnesium & $\mathrm{mg} / \mathrm{L}$ & 114 & Sulfate & $\mathrm{mg} / \mathrm{L}$ & 1739 \\
Aluminum & $\mu \mathrm{g} / \mathrm{L}$ & 15.6 & Potassium & $\mathrm{mg} / \mathrm{L}$ & 11.8 & Chloride & $\mathrm{mg} / \mathrm{L}$ & 56 \\
\hline
\end{tabular}

The crystallization pressures exerted by the precipitation of ettringite and gypsum were calculated for the cases "cylindrical pore" and "spherical pore with small entries" according to Equations (4)-(7). The necessary supersaturation with respect to ettringite and gypsum in the damaged zone was estimated based on equilibrating the initial phase assemblage after $28 \mathrm{~d}$ hydration (Table 7, column 2) with the respective sulfate or groundwater solution (by omitting ettringite and gypsum precipitation). Hence the driving force for the additional gypsum and ettringite formation is mainly related to the conversion of hydrogarnet, monocarbonate and portlandite to ettringite and gypsum.

With help of the previously calculated volume fractions and the estimated supersaturation it is possible to estimate the crystallization pressure resulting from the formation of 
ettringite and gypsum for the individual scenarios according to Equations (4)-(7) assuming cylindrical or spherical pores (for comparison see [29]).

Figure 12 depicts the estimated tensile stress caused by the formation of additional ettringite and gypsum for the aforementioned three scenarios. As a reference, the average tensile strength of 36 briquet specimens prepared with (2) CEM I $42.5 \mathrm{~N}$ and stored in saturated $\mathrm{Ca}(\mathrm{OH})_{2}$ solution for 28 days is shown as a dashed line. It becomes obvious, that for all three scenarios the tensile strength of the concrete is exceeded by the crystallization pressure. Hence cracking and subsequent degradation of the matrix is to be expected.

tensile stress in $\mathrm{N} / \mathrm{mm}^{2}$

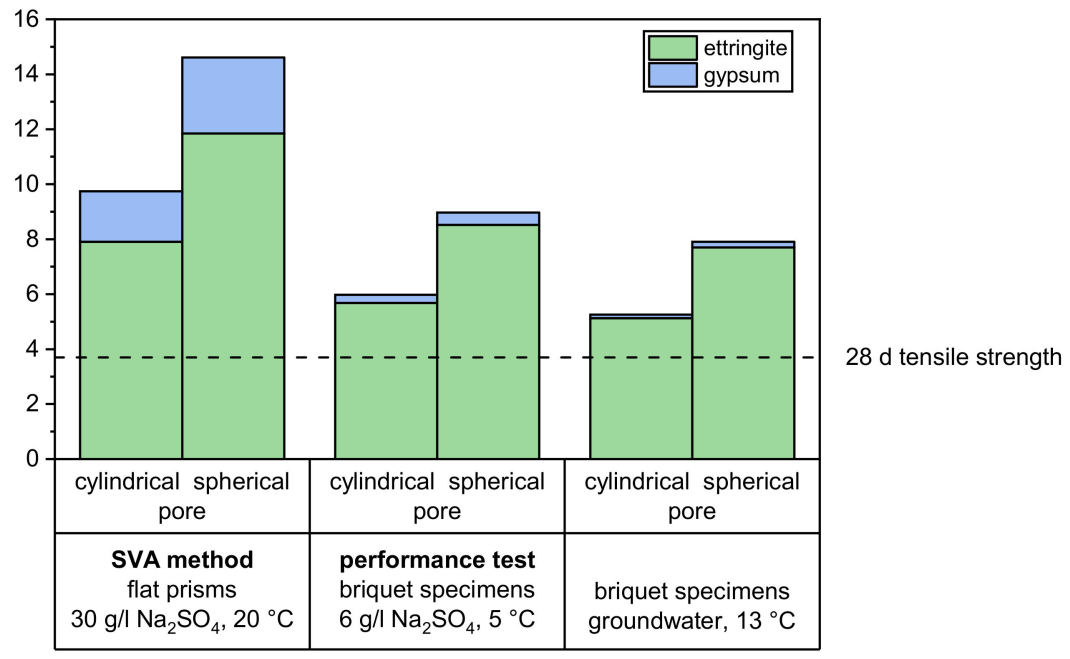

Figure 12. Calculated tensile stress exerted by additional crystallization of ettringite and gypsum induced by sulfate ingress.

Compared to storage of concrete in sulfate containing groundwater the procedure of the SVA method at 30,000 $\mathrm{g} \mathrm{SO}_{4}{ }^{2-} / \mathrm{L}$ results in an overall significantly larger crystallization pressure including a more pronounced formation of gypsum, which accounts for about $19 \%$ of the total crystallization pressure. Storage of briquet specimens in artificial sodium sulfate solution with $6 \mathrm{~g} \mathrm{SO}_{4}{ }^{2-} / \mathrm{L}$ at $5{ }^{\circ} \mathrm{C}$ results in crystallization pressures comparable to those expected when storing the samples in groundwater: the calculated total pressure is about $6.0 \mathrm{~N} / \mathrm{mm}^{2}$ in the case of the cylindrical pore (cf. $5.3 \mathrm{~N} / \mathrm{mm}^{2}$ in groundwater) and $9.0 \mathrm{~N} / \mathrm{mm}^{2}$ for the case of the filled large spherical pore with small entries (cf. $7.9 \mathrm{~N} / \mathrm{mm}^{2}$ in groundwater). The influence of gypsum crystallization on the total pressure exerted is $2 \%$ (performance test) compared to $1 \%$ when storing in groundwater. Based on these results it can be concluded, that the performance test is more suitable to represent field conditions compared to the conventional SVA method.

\section{Conclusions and Outlook}

In this study the applicability of a newly developed performance test method to determine the sulfate resistance of concrete by tensile strength measurements has been demonstrated.

It can be concluded that after at most nine months ( 273 days) of storage in moderate sodium sulfate solution $\left(6000 \mathrm{mg} \mathrm{SO}{ }_{4}{ }^{2-} / \mathrm{L}\right)$ at $5{ }^{\circ} \mathrm{C}$ the sulfate resistance of a specific concrete mixture can be evaluated. Storage for only four months (119 days) was not long enough to produce significant results to distinguish sulfate resistant concrete from concrete susceptible to sulfate attack. For concrete particularly well suited in sulfate rich environment six months (182 days) of storage were long enough to prove the sulfate resistance, whereas concrete with a very low sulfate resistance already showed severe loss in strength after six months.

Based on the results of concrete mixtures with 23 different binders limit values have been defined as thresholds to pass the performance test. After 182 days a relative remaining 
tensile strength of 0.70 or lower means the concrete mixture has failed the test. At a remaining relative tensile strength of more than 0.85 after 182 days the concrete can be considered highly resistant to sulfate attack. For concrete mixtures that exhibit a relative strength between these values strength testing has to be performed after 273 days of storage. At a relative remaining tensile strength of more than 0.70 at this age the concrete mixture can considered highly resistant to sulfate attack.

The results obtained with the new performance test were compared with measurement data from the SVA method that is commonly used in Germany. Concrete or mortar produced with blastfurnace cement CEM III/B, which is known to be highly sulfate resistant, pass both test methods.

The newly developed performance test method is able to assess the sulfate resistance of a concrete mix under practical storage conditions, as has been underlined by thermodynamic calculations. Additionally, the influence of technological parameters (especially the $\mathrm{w} / \mathrm{c}$-ratio and the differing aggregate/cement ratio) can be considered. This provides the concrete-producing industry with a method that can test the sulfate resistance of concrete in a targeted manner.

The reproducibility of the test results should be determined in an intra-laboratory test exemplarily for one concrete mixture. Further comparative lab tests with different concrete formulations are just as necessary as an inter-laboratory test in order to ensure the general suitability and comparability of measurement results.

In conclusion, it can be stated that the newly developed test method

- can evaluate the performance of a practice-oriented concrete,

- considers not only the chemical but also the physical resistance of concrete,

- leads much faster to an evaluation of the sulfate resistance compared to the SVA method (current regulation: testing at $3000 \mathrm{mg} \mathrm{SO}{ }^{2-} / \mathrm{L}$ and $5{ }^{\circ} \mathrm{C}$ for 2 years),

- $\quad$ represents the damage mechanism more realistically compared to most common test methods and therefore leads to fewer test artifacts and

- can also be carried out as a binder test if the concrete recipe is kept constant (e.g., composition according to EN 206 for exposure class XA2).

Supplementary Materials: The following are available online at https:/ /www.mdpi.com/article/10 .3390/cryst11091018/s1.

Author Contributions: Conceptualization, methodology, validation, formal analysis, investigation, data curation, visualization, writing —original draft preparation: J.H. Writing-review and editing, funding acquisition, supervision: A.V. Writing-review and editing, supervision: T.M. All authors have read and agreed to the published version of the manuscript.

Funding: This research was funded by the AiF within the program for sponsorship by Industrial Joint Research (IGF) of the German Federal Ministry of Economic Affairs and Energy based on an enactment of the German Parliament (Project Nr. 19251N).

Data Availability Statement: The data presented in this study are available in Supplementary Materials.

Acknowledgments: This research was conducted in cooperation with the FEhS-Institut für BaustoffForschung e.V., Duisburg, Germany. We thank Andreas Ehrenberg and Volkert Feldrappe for the contribution of measurement data.

Conflicts of Interest: The authors declare no conflict of interest. 


\section{References}

1. Alexander, M.; Bertron, A.; de Belie, N. Performance of Cement-Based Materials in Aggressive Aqueous Environments; Springer: Dordrecht, The Netherlands, 2013; ISBN 978-94-007-5412-6.

2. Skalny, J.; Marchand, J.; Odler, I. Sulfate Attack on Concrete; Spon Press: London, UK, 2002.

3. Borsoi, A.; Collepardi, S.; Coppola, L.; Troli, R.; Collepardi, M. Sulfate Attack on Blended Portland Cements. In Durability of Concrete, Proceedings of the 5th Canmet/ACI International Conference; Barcelona, Spain, 4-9 June 2000, Malhotra, V.M., Ed.; American Concrete Institute: Farmington Hills, MI, USA, 2000; pp. 417-432.

4. Guyot, R.; Ranc, R.; Varizat, A. Comparison of the Resistance to Sulfate Solutions and to Sea Water of Different Portland Cements with or without Secondary Constituents. In Proceedings of the CANMET/ACI First International Conference on the Use of Fly Ash, Silica Fume Slag and Other Mineral By-Products in Concrete, Detroit, MI, USA, 1 May 1983; pp. $453-469$.

5. Tsivilis, S.; Kakali, G.; Skaropoulou, A.; Sharp, J.H.; Swamy, R.N. Use of mineral admixtures to prevent thaumasite formation in limestone cement mortar. Cem. Concr. Comp. 2003, 25, 969-976. [CrossRef]

6. Kunther, W.; Lothenbach, B.; Scrivener, K.L. Deterioration of mortar bars immersed in magnesium containing sulfate solutions. Mater. Struct. 2013, 46, 2003-2011. [CrossRef]

7. Sirisawat, I.; Saengsoy, W.; Baingam, L.; Krammart, P.; Tangtermsirikul, S. Durability and testing of mortar with interground fly ash and limestone cements in sulfate solutions. Constr. Build. Mater. 2014, 64, 39-46. [CrossRef]

8. Heinz, D.; Ludwig, U.; Rüdiger, I. Secondary Ettringite Formation in Mortars and Concretes Subjected to Heat-Treatment. In Dauerhaftigkeit Nichtmetallischer Anorganischer Baustoffe; Abschlußkolloquium des Forschungsschwerpunktprogramm der DFG, Institut für Massivbau und Baustofftechnologie Karlsruhe: Karlsruhe, Germany, 1988; pp. 83-92.

9. Heinz, D.; Urbonas, L. Ergänzende Untersuchungen Zum DAfStb-Verbundforschungsvorhaben "Vertiefte Untersuchungen Zum Sulfatwiderstand Von Beton": Abschlussbericht; DAfStb-Forschungsvorhaben V 469/1: München, Germany, 2012.

10. Fraay, A.L.A.; Reigersman, A.; de Pee, J. Sulfate Resistance of Mortars with Pulverized Fuel Ash. In Concrete Durability, Proceedings of the International Conference, Atlanta, GA, USA 27 April-1 May 1987; Mather, K., Mather, B., Eds.; American Concrete Institute: Farmington Hills, MI, USA, 1987; pp. 2041-2058.

11. Al-Dulaijan, S.U.; Maslehuddin, M.; Al-Zahrani, M.M.; Sharif, A.M.; Shameem, M.; Ibrahim, M. Sulfate resistance of plain and blended cements exposed to varying concentrations of sodium sulfate. Cem. Concr. Comp. 2003, 25, 429-437. [CrossRef]

12. Messad, S.; Carcasses, M.; Linger, L.; Boutillon, L. Performance Approach Using Accelerated Test Method for External Sulfate Attack. In Proceedings of the Third International Fib Conference, Incorporating PCI Annual Convention Bridge Conference, Washington, DC, USA, 29 May-2 June 2010.

13. Monteiro, P.J.M.; Kurtis, K.E. Time to failure for concrete exposed to severe sulfate attack. Cem. Concr. Res. 2003, 33, 987-993. [CrossRef]

14. Cao, H.T.; Bucea, L.; Ray, A.; Yozghatlian, S. The effect of cement composition and pH of environment on sulfate resistance of Portland cements and blended cements. Cem. Concr. Comp. 1997, 19, 161-171. [CrossRef]

15. Dhole, R.; Thomas, M.D.A.; Folliard, K.J.; Drimalas, T. Characterization of Fly Ashes for Sulfate Resistance. ACI Mater. J. 2013, $110,159-168$.

16. Ramyar, K.; Inan, G. Sodium sulfate attack on plain and blended cements. Build. Environ. 2007, 42, 1368-1372. [CrossRef]

17. Steindl, F.R.; Baldermann, A.; Galan, I.; Sakoparnig, M.; Dietzel, M.; Mittermayr, F. A new test for combined Ca-leaching and sulphate resistance of cementitious materials. MATEC Web Conf. 2018, 199, 2005. [CrossRef]

18. Donatello, S.; Palomo, A.; Fernández-Jiménez, A. Durability of very high volume fly ash cement pastes and mortars in aggressive solutions. Cem. Concr. Comp. 2013, 38, 12-20. [CrossRef]

19. Bhatty, M.S.Y. Properties of Blended Cements Made with Portland Cement, Cement Kiln Dust, Fly Ash and Slag. In Proceedings of the 8th International Congress on the Chemistry of Cement, Rio de Janeiro, Brazil, 22-27 September 1986; pp. 118-127.

20. Wittekindt, W. Sulfatbeständige Zemente und ihre Prüfung. Zement-Kalk-Gips 1960, 13, 565-572.

21. Haufe, J.; Vollpracht, A.; Brameshuber, W. Sulfate Resistance Testing in Germany-Critical Review. In Concrete 2015, Proceedings of the 27th Biennial National Conference of the Concrete Institute of Australia in Conjunction with the 69th RILEM Week, Melbourne, Australia, 30 August-2 September 2015; Sanjayan, J., Sagoe-Crentsil, K., Eds.; Concrete Institute of Australia: West Perth, Australia, 2015.

22. Haufe, J.; Vollpracht, A. Tensile strength of concrete exposed to sulfate attack. Cem. Concr. Res. 2019, 116, 81-88. [CrossRef]

23. Mulenga, D.M. Zum Sulfatangriff auf Beton und Mörtel einschließlich der Thaumasitbildung. Ph.D. Thesis, Bauhaus-Universität Weimar, Weimar, Germany, 2002.

24. Neunzig, C.; Heiermann, T.; Raupach, M. Determination of the Uniaxial Tensile Strength of Concrete with a Modified Test Setup. In Strain-Hardening Cement-Based Composites, SHCC4, Proceedings of the International Conference on Strain-Hardening CementBased Composites, Dresden, Germany, 20 September 2017; Mechtcherine, V., Slowik, V., Kabele, P., Eds.; Springer: Dordrecht, The Netherlands, 2017; pp. 316-323.

25. Haufe, J.; Vollpracht, A.; Matschei, T. Development of a Sulfate Resistance Performance Test for Concrete by Tensile Strength Measurements: Determination of Test Conditions. Crystals 2021, 11, 1001. [CrossRef]

26. Suherman, P.M.; van Riessen, A.; O'Connor, B.; Li, D.; Bolton, D.; Fairhurst, H. Determination of amorphous phase levels in Portland cement clinker. Powder Diffr. 2002, 17, 178-185. [CrossRef]

27. Vollpracht, A.; Soutsos, M.; Kanavaris, F. Strength development of GGBS and fly ash concretes and applicability of fib model code's maturity function-A critical review. Constr. Build. Mater. 2018, 162, 830-846. [CrossRef] 
28. FIB. Fib Model Code for Concrete Structures 2010; Ernst \& Sohn: Berlin, Germany, 2013; ISBN 9783433604083.

29. Flatt, R.J.; Scherer, G.W. Thermodynamics of crystallization stresses in DEF. Cem. Concr. Res. 2008, 38, 325-336. [CrossRef]

30. Kulik, D.A.; Wagner, T.; Dmytrieva, S.V.; Kosakowski, G.; Hingerl, F.F.; Chudnenko, K.V.; Berner, U.R. GEM-Selektor geochemical modeling package: Revised algorithm and GEMS3K numerical kernel for coupled simulation codes. Comput. Geosci. 2013, 17, 1-24. [CrossRef]

31. Lothenbach, B.; Kulik, D.A.; Matschei, T.; Balonis, M.; Baquerizo, L.; Dilnesa, B.; Miron, G.D.; Myers, R.J. Cemdata18: A chemical thermodynamic database for hydrated Portland cements and alkali-activated materials. Cem. Concr. Res. 2019, 115, 472-506. [CrossRef]

32. Haufe, J.; Vollpracht, A.; Brameshuber, W. Sulfate Ingress on Fly Ash Containing Mortar Samples. In Proceedings of the 2nd International Congress on Durability of Concrete, New Delhi, India, 4-6 December 2014.

33. Parrot, L.J.; Killoh, D.C. Prediction of cement hydration. Br. Ceram. Proc. 1984, 35, 41-53. 